Bundesgesundheitsbl 2015 · 58:1351-1370 DOI 10.1007/s00103-015-2255-x

Online publiziert: 20. Oktober 2015

c) Springer-Verlag Berlin Heidelberg 2015

CrossMark
Mitteilungen des Arbeitskreises Blut des Bundesministeriums für Gesundheit

\section{Humanes Immunschwächevirus (HIV)}

\section{Stellungnahmen des Arbeitskreises Blut des Bundesministeriums für Gesundheit}

Der Arbeitskreis Blut des Bundesministeriums für Gesundheit gibt als nationales Beratungsgremium Stellungnahmen zu neuartigen Erregern ab, bewertet neue Erkenntnisse zu bekannten Erregern und erarbeitet entsprechende Empfehlungen für die Fachöffentlichkeit. Diese Serie von Stellungnahmen zu einzelnen Erregern wird als Zusammenfassung des aktuellen Wissensstandes veröffentlicht, speziell unter transfusionsmedizinisch relevanten Aspekten (Bundesgesundheitsbl. 41, 53, 1998).

Frühere Beiträge befassten sich mit der Creutzfeldt-Jakob-Erkrankung, dem Parvovirus B19 und dem GB-Virus Typ $C$ (Hepatitis-G-Virus) (Bundesgesundheitsbl. 41, 78-90, 1998), HTLV 1/2 (Bundesgesundheitsbl. 41, 512-517, 1998), Yersinia enterocolitica (Bundesgesundheitsbl. 42, 613-621, 1999), TT-Virus (Bundesgesundheitsbl. 43, 154-156, 2000), Hepatitis-B-Virus (HBV) (Bundesgesundheitsbl. 43, 240-248, 2000), Humanes Cytomegalovirus (HCMV) (Bundesgesundheitsbl. 43, 653-659, 2000), Hepatitis- $A$ Virus (Bundesgesundheitsbl. 44, 844850,2001 ), Treponema pallidum (Bundesgesundheitsbl. 45, 818-826, 2002), Нераtitis-C-Virus (Bundesgesundheitsbl. 46, 712-722, 2003), Humanes Immunschwächevirus (HIV) (Bundesgesundheitsbl. 47, 83-95, 2004), Arboviren - durch Arthropoden übertragbare Viren (Bundesgesundheitsbl. 47, 910-918, 2004), Coxiella burnetii - Erreger des Q (query)-Fiebers (Bundesgesundheitsbl. 48, 814-821, 2005), Variante Creutzfeldt-Jakob-Krankheit (Bundesgesundheitsbl. 48, 10821090, 2005), Influenzaviren (Bundesgesundheitsbl. 50, 1184-1191, 2007), Arbobakterien (über Arthropoden übertragba- re Bakterien) (Bundesgesundheitsbl. 50, 1192-1207, 2007), Hepatitis-E-Virus (Bundesgesundheitsbl. 51, 90-97, 2008), Malaria (Bundesgesundheitsbl. 51, 236-249, 2008), Arboprotozoen (Bundesgesundheitsbl. 52, 123-146, 2009), Orthopockenviren: Infektionen des Menschen (Bundesgesundheitsbl. 53, 957-972, 2010), Humanes Cytomegalievirus (HCMV) (Bundesgesundheitsbl. 53, 973-983, 2010), Parvovirus B19 (Bundesgesundheitsbl. 53, 944956, 2010), Dengue-Fieber-Virus (DENV) (Bundesgesundheitsbl.54, 892-903,2011), $X M R V$ (Bundesgesundheitsbl. 55, 10571060, 2012), Arbonematoden - durch Arthropoden übertragbare Nematoden-Infektionen (Bundesgesundheitsbl. 55, 10441056, 2012), West-Nil-Virus (Bundesgesundheitsbl. 55, 1024-1043, 2012), Coxiella burnetii - Erreger des Q (query)-Fiebers (Bundesgesundheitsbl.56,1178-1190, 2013), Usutuvirus (Bundesgesundheitsbl. 56,1168-1177,2013) und Hepatitis-E-Virus (Bundesgesundheitsbl.58, 198-218, 2015).

\section{Wissensstand über den Erreger}

\subsection{Erreger-Eigenschaften}

Das humane Immunschwächevirus ( $h u$ man immunodeficiency virus, HIV) gehört innerhalb der Familie der Retroviren zur Subfamilie Orthoretrovirinae, Genus Lentiviren, [1]. HIV wird auf Grund von genetischen Eigenschaften und Unterschieden in den Antigenen in die Typen 1 und 2 eingeteilt (HIV-1 und HIV-2). Als SIV werden die Immunschwäche-Viren der Affen (simian immunodeficiency virus) bezeichnet, die auch zum Genus Lentivirus zählen. Die bisher vorliegenden epi- demiologischen und molekularbiologischen Daten weisen darauf hin, dass etwa um 1920 bis 1940 HIV-1 von zentralafrikanischen Schimpansen (SIVcpz) und HIV-2 von westafrikanischen Mangaben (SIVsm) auf den Menschen übertragen wurden [2-4].

\subsubsection{HIV-1}

Genomaufbau. Das Genom von HIV besteht aus zwei identischen Molekülen RNA, die im Kapsid (core) des Viruspartikels verpackt sind. Das Genom des HIVProvirus (siehe 1.1.3), auch provirale DNA genannt, entsteht durch die reverse Transkription der viralen RNA in DNA und Abbau der RNA und wird in das menschliche Genom integriert. Das DNA-Genom ist an beiden Enden von LTR- (long terminal repeat) Regionen flankiert (• Abb. 1). Die LTR-Region trägt am 5' Ende den Promotor zur Transkription des viralen Genoms. In Leserichtung 5'- 3' folgt der gag-Leserahmen, welcher für die Proteine der äußeren Kernmembran (MA, p17), des Kapsidproteins (CA, p24), des Nukleokapsids (NC, p7) und kleinere, die Nukleinsäure stabilisierende Proteine kodiert (siehe $\bullet$ Abb. 1 und 3). Weiter in Leserichtung folgt der pol-Leserahmen, welcher die Enzyme Protease (PR, p12), reverse Transkriptase (RT, p51) plus RNase $\mathrm{H}$ (p15; RT plus RNase H zusammen p66) und die Integrase (IN, p32) kodiert. Anschließend folgt der $e n v$-Leserahmen, von welchem die beiden Hüll-Glykoproteine gp120 (surface protein, SU) und gp41 (transmembrane protein, TM) exprimiert werden. Das Genom von HIV kodiert für mehrere regulatorische Proteine: Tat (transactivator protein) und Rev (RNA- 


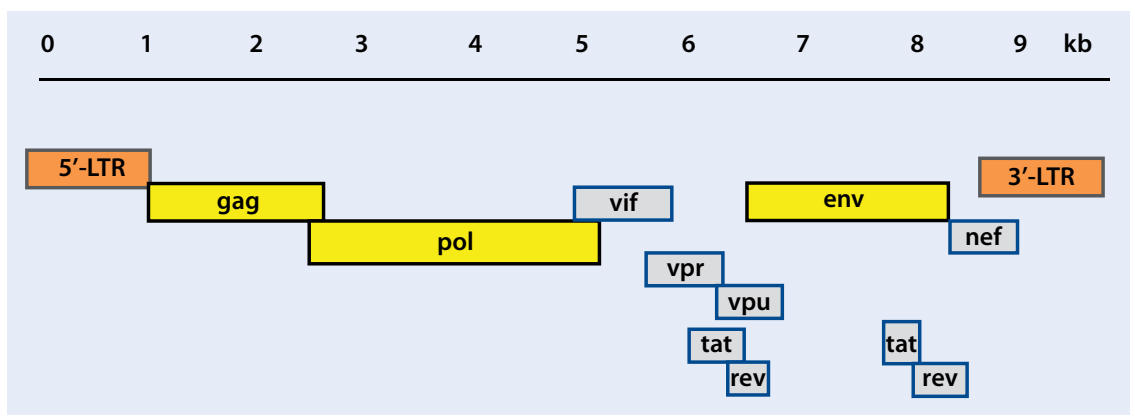

Abb. $1 \Delta$ Genomaufbau von HIV-1. LTR bedeutet long terminal repeat, gag - group specific antigen, pol - polymerase, env - envelope. Bei den Regulatorgenen werden die Proteine Tat und Rev aus zwei Exons zusammengesetzt. Bei HIV-2 entspricht das vpu- dem vpx-Gen. Die LTR-Nukleinsäure-Sequenzen werden nicht zu Protein translatiert. Das HIV-1-Genom besteht aus etwa 9.200 bis 9.600 Nukleotiden, das HIV-2-Genom aus bis zu 9.800 Nukleotiden [5]. Grafik mit freundlicher Genehmigung von Lutz Gürtler

splicing regulator) sind für die Initiation der HIV-Replikation notwendig. Die weiteren regulatorischen Proteine Nef (negative regulating factor), Vif (viral infectivity factor), $\mathrm{Vpr}$ (virus protein $r$ ) und $\mathrm{Vpu}(v i-$ rus protein $u$ ) beeinflussen die Geschwindigkeit der HIV-Replikation, der Ausknospung der Viruspartikel und die Pathogenese (Übersicht in - Tab. 1) [5, 6]. HIV-2 enthält statt Vpu ein Vpx (virus protein $x$ ), welches partiell für die geringere Pathogenität von HIV-2 verantwortlich ist [7]. SIVcpz, das Simian Immundeficiency Virus von Schimpansen und das SIVgor von Gorillas haben einen identischen Genomaufbau wie HIV-1 [8].

HIV-Gruppen und Subtypen. HIV-1 wird untergliedert in die Gruppen $\mathrm{M}, \mathrm{N}$ ([9], $\mathrm{O}$ und $\mathrm{P}[10,11]$; $\bullet$ Abb. 2). Verschiedene Schimpansenviren lassen sich nach phylogenetischen Analysen zwischen die beim Menschen vorkommenden Gruppen $\mathrm{N}$ und $\mathrm{O}$ einordnen $[2,3,12]$ und die Gruppe P unter die SIV der Gorillas (SIVgor). Es ist unklar, ob das Schimpansenvirus der Gruppe P direkt vom Schimpansen oder vom Gorilla auf den Menschen übertragen wurde.

HIV-1 Gruppe M wird unterteilt in die Subtypen A bis D, F bis H, J und K, von denen $\mathrm{A}$ und $\mathrm{D}$ evolutionär die ältesten Viren zu sein scheinen. Subtypen B und $\mathrm{D}$ sind so eng miteinander verwandt, dass sie heute als Sub-Subtypen bezeichnet werden. Rekombinante Viren leiten sich von verschiedenen Subtypen ab und werden als CRF - circulating recombinant form bezeichnet, die etwa $20 \%$ der Diversität der Gruppe M Viren ausmachen [13].
Der vormals beschriebene Subtyp E beispielsweise ist nur im Hüllgen (env) individuell, während der übrige Genomanteil dem HIV-1 M:A entspricht, und wird heute als HIV-1 M: CRF01_AE bezeichnet [8]. Subtyp I ist ebenfalls ein rekombinantes Virus (CRF04_cpx) und deswegen nicht mehr in der A-K-Listung enthalten. Es sind mehr als 70 verschiedene, epidemiologisch stabile CRF beschrieben worden [8, 14-16]; die Bildung weiterer CRF ist zu erwarten.

Rekombination, d. h. Austausch ganzer Genbereiche an nicht selektionierten Stellen, beobachtet man bei Infektion von Zellen mit z. B. zwei unterschiedlichen HIV-Subtypen bei etwa 1 von 400 gebildeten Partikeln [17]. Durch Rekombination bilden sich genetisch neue Stämme, die innerhalb des Wirtes einen Selektionsvorteil haben können, z. B. HIV-1 M:A/G (heute CRF02_AG) in Westafrika und B/C (CRF07_BC und CRF08_BC) in China $[12,13]$. Rekombinanten zwischen HIV-1-Gruppen, z. B. Gruppe M Subtyp $A$ und Gruppe $O$, sind in Kamerun gefunden worden [18], bisher jedoch nicht zwischen HIV-1 und HIV-2. Für Gruppe OViren $[19,20]$ ist eine Einteilung in Subtypen I bis VI oder A bis C vorgeschlagen worden $[21,22]$, jedoch bildet sich kein typischer evolutionärer Baum wie bei Gruppe M beschrieben [23] - siehe auch $\bullet$ Abb. 2 -, was auf eine andere Evolution der Gruppe O-Viren seit Übertragung auf den Menschen hinweist [4]. Da von Gruppe N [9] nur etwa 15 Infizierte bekannt sind und von Gruppe P bisher nur zwei [23], erübrigt sich die Erstellung eines phylogenetischen Baums.
Partikelaufbau. Das reife HIV-Partikel ist rund, hat einen Durchmesser von ca. $100 \mathrm{~nm}$ und eine äußere Lipidmembran als Hülle (• Abb. 3). In der Hülle stecken 72 Knöpfe, die aus Trimeren des gp120Oberflächenproteins (SU) bestehen, die über das Trimer des Transmembranproteins gp41 (TM) in der Membran verankert sind [24]. Auf dem gp120 liegen konformationsabhängige neutralisierende Epitope, die im nativen Protein ausgebildet sind, im entfalteten, denaturierten Protein nur teilweise [25]. Die Virushülle aus Lipiden, gp120 und gp41 bedeckt die aus dem Matrixprotein (MA, p17) symmetrisch aufgebaute äußere Kapsidmembran. Das kegelförmige Kapsid ist aus dem inneren Kapsidprotein p24 (CA) aufgebaut [26]. Je nach Schnittrichtung ist das Kapsid im elektronenmikroskopischen Bild als Kegel, Ring oder Ellipse zu erkennen (- Abb. 3). Das Kapsid ist an der äußeren Kapsidmembran mit dem verjüngten Pol fixiert. Im Kapsid befinden sich zwei identische Moleküle viraler genomischer RNA und mehrere Moleküle RT/RNase $\mathrm{H}$ und IN, die an der Nukleinsäure haften [1]. Im Viruspartikel ebenfalls vorhanden sind Oligopeptide, die durch die Protease bei der Prozessierung der Vorläuferproteine von Gag und Pol (p160) nach der Zellausschleusung des Partikels während der Partikelreifung freigesetzt wurden.

Die Reifung von HIV erfolgt nach Abschluss des Budding-Prozesses und der Freisetzung des Virus von der Zellmembran durch Spaltung des Gag- und Gag/ Pol-Vorläuferproteins (p55, p160) in die Einzelproteine. In elektronenmikroskopischen Aufnahmen kann nach Ausschleusung der Verlust der Oberflächenfortsätze (SU-Trimere) über Scherkräfte - sog. shedding - beobachtet werden [27]. Gp120-freie Partikel sind nicht mehr infektionstüchtig [28].

Regulator-Proteine. Tat beschleunigt die Verfügbarkeit von viraler RNA 100-fach. Tat bindet nur an die TAR-Region von viraler RNA, nicht jedoch an zelluläre RNA. Tat aktiviert in Trans-Position auch weitere HIV-Genome in der Zelle. Tat selbst wird induziert durch Tat, aber auch durch Zytokine wie p65, eine Untereinheit von NF kappa B, und durch NF kappa B [29]. 


\begin{tabular}{|c|c|c|c|}
\hline Gen & $\mathrm{Größe}^{\mathrm{a}}$ & Protein & Funktion \\
\hline \multirow[t]{4}{*}{ Gag } & p24 & Kapsid-Protein (CA) & Aufbau des kegelförmigen Kapsids \\
\hline & p17 & Matrix-Protein (MA) & Aufbau der äußeren Kapsid-Membran \\
\hline & p6 & & $\begin{array}{l}\text { Beeinflusst Freisetzung von Viruspartikeln, Interaktion mit } \\
\text { Vpr }\end{array}$ \\
\hline & p7 & Nukleoprotein & bindet an die RNA und bildet den Nukleoprotein-Komplex \\
\hline \multirow[t]{4}{*}{ Pol } & p10 & Protease (PR) & $\begin{array}{l}\text { Spaltung des Gag-Pol-Vorläufer-Proteins, Freisetzung der } \\
\text { Struktur-Proteine und Enzyme }\end{array}$ \\
\hline & p51 & $\begin{array}{l}\text { Reverse Transkrip- } \\
\text { tase (RT) }\end{array}$ & Umschreibung der HIV-RNA in DNA \\
\hline & $\begin{array}{l}\text { p15 } \\
(66)\end{array}$ & RNase $\mathrm{H}$ & Abbau der viralen RNA im RNA/DNA-Replikationskomplex \\
\hline & p32 & Integrase (IN) & Einbau der proviralen DNA ins Genom \\
\hline \multirow[t]{2}{*}{ Env } & gp120 & $\begin{array}{l}\text { Oberflächenglyko- } \\
\text { protein (SU) }\end{array}$ & Anheftung an Zelle \\
\hline & gp41 & $\begin{array}{l}\text { Transmembranpro- } \\
\text { tein (TM) }\end{array}$ & Verankerung von gp120, Fusion \\
\hline Tat & p14 & $\begin{array}{l}\text { Transaktivator- } \\
\text { Protein }\end{array}$ & Regelung der Proteinsynthese über RNA \\
\hline Rev & p19 & $\begin{array}{l}\text { RNA splicing regu- } \\
\text { lator }\end{array}$ & Regelung der mRNA-Länge \\
\hline Nef & p27 & $\begin{array}{l}\text { Negative regula- } \\
\text { ting factor }\end{array}$ & $\begin{array}{l}\text { Beeinflussung der HIV-Replikation, Verminderung der CD4- } \\
\text { und HLA- Expression auf der Zelloberfläche }\end{array}$ \\
\hline Vif & p23 & $\begin{array}{l}\text { Viral infectivity } \\
\text { protein }\end{array}$ & Beschleunigung der HIV-Freisetzung und Reifung \\
\hline Vpr & p15 & Virus protein $r$ & $\begin{array}{l}\text { Erleichterung der Virusproteinsynthese, Beeinflussung des } \\
\text { Zellzyklus der HIV-infizierten Zelle }\end{array}$ \\
\hline Vpu & p16 & Virus protein u & $\begin{array}{l}\text { Erleichterung der Virus-Freisetzung (HIV-1), beschleunigt } \\
\text { den Abbau von CD4 im Endoplasmatischen Retikulum }\end{array}$ \\
\hline Vpx & p15 & Virus protein $\mathrm{x}$ & Erhöhung der Infektiosität bei HIV-2 \\
\hline Tev & p26 & Tat/Rev-Protein & Regelt die Aktivität von Tat und Rev im Zellkern \\
\hline
\end{tabular}

Rev ist verantwortlich für die Spleißlänge der gebildeten HIV-RNA. Dadurch wird ermöglicht, dass die Regulatorproteine früh während des Replikationszyklus und die Strukturproteine erst spät gebildet werden.

Nef beeinflusst die Präsentation von CD4-Molekülen auf der Zelloberfläche negativ, folglich verarmt die Membran der infizierten Zelle an CD4, so dass sie von weiteren HIV nicht mehr infiziert werden kann (siehe unten) und die zelluläre Immunreaktion gegen die infizierte Zelle verlangsamt ist. Ferner steigert Nef die pathogene Wirkung in vivo [5]. Nef von HIV-1 besteht aus weniger Aminosäuren und steigert die Pathogenität mehr als bei HIV-2. Weitere Regulatorproteine sind Vif, vpr und vpu, die einen Einfluss auf die Geschwindigkeit der HIV-Produktion ausüben $[8,30,31]$. wird nur Gruppe A weiter in die Subtypen A1 und A2 unterteilt [36, 37]. Wegen der ausgeprägten Unterschiede in der Antigenität der viralen Proteine und im Genomaufbau zu HIV-1 erfordert die HIV2-Diagnostik virusspezifische Reagenzien. NAT-Teste für die quantitative Bestimmung von HIV-2-Nukleinsäure sind seit 2012 kommerziell verfügbar [38]. HIV-2 ist wie erwähnt im Allgemeinen weniger pathogen als HIV-1.

\subsubsection{Infektion der menschlichen Zelle}

Die ersten Schritte der Infektion einer Zelle sind durch komplexe Protein-Protein-Wechselwirkungen gekennzeichnet. Das reife HIV-Partikel bindet mit dem gp120-Protein an den CD4-Rezeptor der Wirtszelle. Empfängliche Zellen für den HIV-Eintritt sind somit alle CD4-positiven Zellen, wie T-Helfer-Lymphozyten, Makrophagen, dendritische Zellen und Astrozyten. Nach Anheftung an das CD4Molekül über die C4-Domäne des gp120 erfolgt eine Konformationsänderung von CD4 und gp120, die eine weitere Bindungsstelle des gp120 an den sog. Korezeptor, Chemokinrezeptor 5 (CCR5) oder Chemokinrezeptor 4 (CXCR4 oder Fusin) auf der Zelloberfläche eröffnet [39, 40]. Durch Bindung des gp120 an CD4 und den Korezeptor erfolgt eine weitere Konformationsänderung des gp120, nachfolgend eine des gp41 $[1,41]$. Der N-terminale Anteil des gp41 wird aus der Virushülle auf die Zelloberfläche gestülpt, bildet einen Kanal und inseriert auf Grund seiner hohen Hydrophobizität in die Plasmamembran der Zielzelle. Fusion von Zellmembran und Virushülle werden nachfolgend vollzogen.

Nach Verschmelzen beider Membranen befindet sich das Kapsid im Zytoplasma. Das Kapsid wird über ein Endosom aufgenommen, und durch $\mathrm{pH}$-WertÄnderung im Phagosom wird der Kapsidinhalt ins Zytoplasma freigesetzt [42]. Im Zytoplasma erfolgt die Aktivierung der reversen Transkriptase (RT). Die HIVRT schreibt einen HIV-RNA-Strang in DNA (komplementäre DNA, cDNA) um, gleichzeitig wird der RNA-Strang durch die Aktion der RNase $\mathrm{H}$ abgebaut. Durch die RNA-DNA-Polymerase-Aktivität der RT wird an der Einzelstrang-cDNA die 


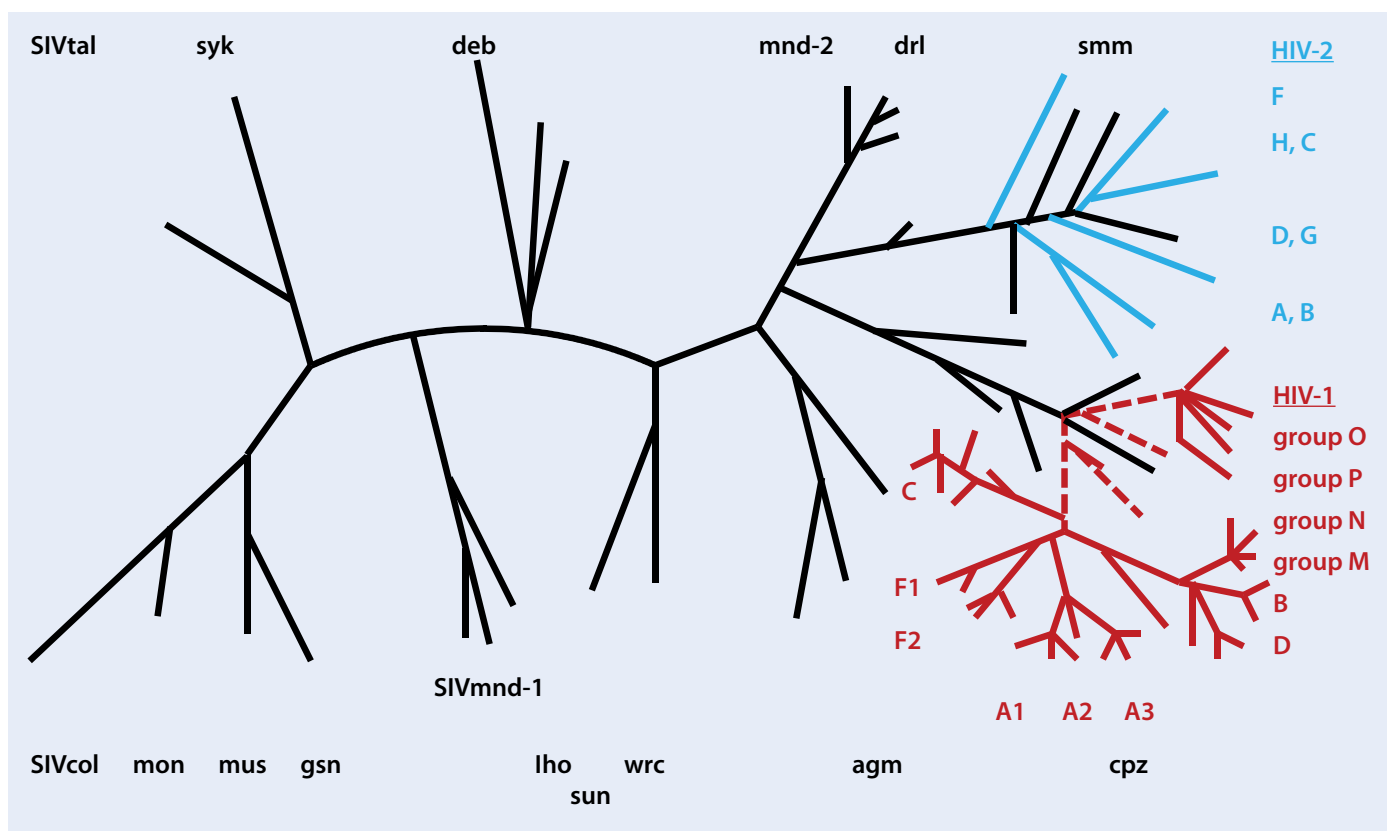

Abb. $2 \Delta$ Schema des phylogenetischen Baums der Primaten-Lentiviren im pol-Bereich, die dem HIV ähnlich sind. Auf der rechten Seite in rot ist HIV-1 mit den Gruppen M, N, O und P (gestrichelt) zu sehen. Die Verzweigung innerhalb der Gruppen $M$ und $O$ entsprechen den Subtypen; Gruppe N und P bestehen nicht aus Subtypen. HIV- 1 hat sich aus verschiedenen Übertragungen des SIVcpz des Schimpansen (Pan troglodytes troglodytes) entwickelt, nicht jedoch von Pan troglodytes schweinfurthii. Das SIVgor der Gorillas (Gorilla gorilla) fällt mit HIV-1 Gruppe P zusammen und ist nicht dargestellt. HIV-2 und seine Gruppen A bis $\mathrm{H}$ (in blau) fallen phylogenetisch mit den Viren der Mangaben (SIVsmm - sooty mangabey monkey, Cercopithecus atys) zusammen. Im Mandrill (SIVmnd, Mandrillus sphinx) wurden zwei verschiedene SIV gefunden. Col ist die Abkürzung für Colobus-Affen (Colobus guereza), gsn für Weißnasenaffen (greater spot nosed monkey, Cercopithecus nictitans), mon für Mona-Affen (Cercopithecus mona), mus für Bart-Affen (Cercopithecus cephus), deb für De Brazza-Affen (Cercopithecus neglectus), drl für Drill-Affen (Mandrillus leucophaeus), Iho für die Gruppe der L'hoesti-Affen (Cercopithecus I'hoesti), sun - sun tailed monkey (Gabun-Meerkatze, Cercopithecus solatus), syk für Sykes-Affen (Cercopithecus albogularis), tal für Talapoin-Affen (Miopithecus oguensis),wrc - western red colobus (Procolobus badius), agm für Afrikanische grüne Meerkatze (Chlorocebus tantalus, C aethiops, ( vervet). Das Schema des phylogenetischen Baumes der SIV der Primaten und HIV wurde erstellt in Anlehnung an Sharp and Hahn, 2011 [3]; Santiago et al., 2005 [32]; Aulicino et al., 2012 [110]; Aghokeng et al., 2010 [218] und Holmes et al, 1995 [219]

Doppelstrang-DNA gebildet und gleichzeitig der zweite RNA-Strang durch die RNase H abgebaut [43]. Die provirale DNA wird als linearer Strang oder als Ring zusammen mit der Integrase (IN) als Komplex über Nukleoporen in den Zellkern transportiert. Die Integrase fügt anschließend das provirale Genom an beliebiger Stelle in das Genom der humanen Wirtszelle ein. Mit der Integration ist die HIV-Infektion der Zelle abgeschlossen und eine permanente Infektion etabliert.

Das provirale Genom wird entweder als Bestandteil des Wirtszellgenoms mit diesem bei Zellteilung vermehrt (latente Infektion - selten). Bei Aktivierung der Zelle dient der LTR-Promotor als Anheftungsregion zellulärer RNA-Polymerasen und verschiedener Transkriptionsfaktoren zur Synthese von viraler mRNA und genomischer RNA. Die Synthese viraler mRNA in voller Länge wird unter ande- rem durch Tat reguliert und maximal aktiviert [44].

Die Anlagerung von HIV an eine CD4Zelle dauert etwa 30 Minuten bis 2 Stunden, die Umschreibung der RNA in HIVDNA etwa 6 Stunden und die Integration weitere 6 Stunden. Nach Integration können erste Viruspartikel nach etwa 12 Stunden produziert werden; d. h. etwa 24 Stunden nach Infektion können erste Nachkommenviren freigesetzt werden. Da die RT keine proof-reading-Aktivität hat, wird bei jedem Umschreibevorgang geschätzt ein Nukleotid falsch eingebaut. Bei ungehemmter HIV-Replikation werden täglich $10^{8}$ bis $10^{9}$ Viren umgesetzt, d. h. vom Immunsystem zerstört und von infizierten Zellen wieder neu produziert [45-47]. Bei einer Mutationsrate von 1 in $10^{4}$ entstehen folglich in einem Patienten über die Zeit verschiedene infektiöse Quasispezies, die, da auch Epitope für neutra- lisierende Antikörper betroffen sind, immer wieder dem Immunsystem entkommen und die HIV-Produktion aufrecht erhalten $[25,29]$. Nicht alle Nukleotid-Austausche führen zum Austausch einer Aminosäure. Mutationen, die essentielle Regionen von Strukturproteinen oder aktive Zentren von Enzymen betreffen, führen zu nicht vermehrungsfähigen HIVMutanten.

Im Blut eines HIV-Infizierten werden mit einer Halbwertszeit von 2-4 Tagen die infizierten T-Lymphozyten über zytotoxische HIV-Komponenten oder durch die Immunabwehr von zytotoxischen T-Lymphozyten zerstört [48, 49]. Da auch HIVinfizierte T-Helfer-Lymphozyten lysiert werden und gleichzeitig deren Nachbildung gehemmt ist, resultiert über die Zeit ein Mangel an T-Helfer-Lymphozyten. Für die unzureichende Nachreifung von T-Helfer-Lymphozyten sind HIV-Protei- 


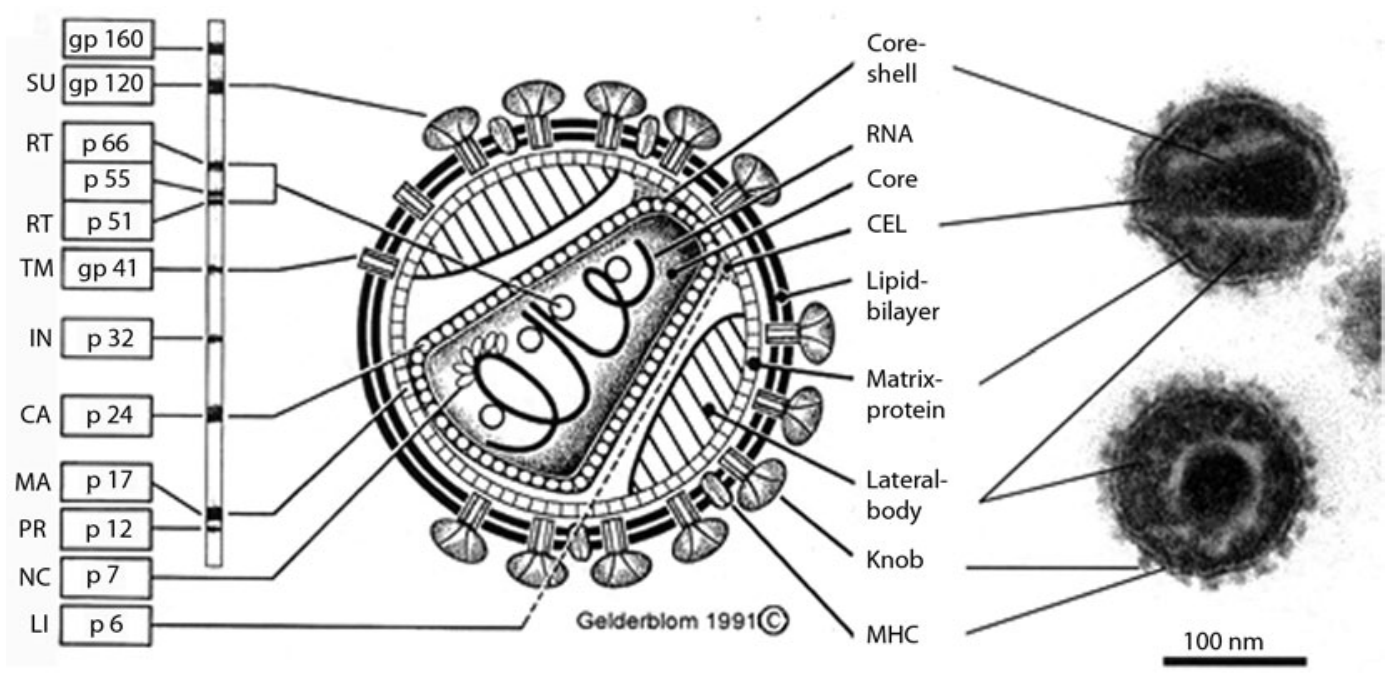

Abb. $3 \Delta$ Schematischer Aufbau des HIV-Partikels und entsprechendes elektronenmikroskopisches Bild auf der rechten Seite und die Banden des Immunoblots auf der linken. gp Glykoprotein, $p$ Protein, SU surface protein, TM transmembrane protein, RT reverse transcriptase, IN integrase, CA capsid protein, MA matrix protein, PR protease, NC nucleic acid-binding protein, LI link protein. MHC sind HLA-Antigene (major histocompatiblity complex), die von der infizierten Zelle stammen. Die Lokalisation der Gene, die für die verschiedenen Proteine kodieren, sind in $\bullet \mathbf{A b b} .1$ dargestellt. $\bullet$ Tab. 1 fasst die Funktion der verschiedenen Proteine zusammen. Bild mit freundlicher Genehmigung von Hans Gelderblom, RKI Berlin

ne wie z. B. Nef und Tat verantwortlich [29]. Ein Teil der neugebildeten T-Helfer-Lymphozyten erreicht keine normale Funktion [47]. Nach jahrelanger Infektion führt der Schwund an T-Helfer-Lymphozyten zur Immunschwäche. Integriertes HIV kann in langlebigen Zellen, wie einigen Makrophagen, Astrozyten oder Memory-T-Zellen, über viele Jahre (Halbwertszeit bestimmter Zielzellen: 7 Jahre) latent überdauern und nach Aktivierung neue Viruspartikel bilden.

\subsubsection{Inaktivierbarkeit und Stabilität von HIV unter Umweltbedingungen}

Die Stabilität von HIV ist wesentlich durch seine Lipidhülle geprägt. HIV ist einige Stunden stabil bei pH-Werten zwischen $\mathrm{pH} 3$ und $\mathrm{pH} 10$ [50, 51]. HIV ist gegenüber der Behandlung mit Desinfektionsmitteln empfindlich. Bereits $20 \%$ Ethanol verringert langsam den Infektionstiter. $70 \%$ Ethanol, $50 \%$ Isopropanol, 4\% Formaldehyd und Peressigsäure sowie starke Detergenzien wie SDS (Natriumdodecylsulfat), NP-40 oder Triton X100 ab 1\% inaktivieren HIV innerhalb weniger Minuten [50, 52].

HIV-Partikel sind gegen physikalische Einflüsse wie z. B. UV-Licht, Gammastrahlen oder Ultraschallwellen für Stunden stabil $[53,54]$. So wurde HIV im
Gegensatz zu anderen Viren in mit UVCLicht behandelten Thrombozytenkonzentraten nur geringfügig inaktiviert [55].

Temperaturabhängigkeit der Inaktivierung

Gegenüber Hitzeeinwirkung in Lösung beträgt die Halbwertzeit $(\mathrm{t} / 2)$ der Virusinaktivierung bei $56^{\circ} \mathrm{C}$ etwa $30 \mathrm{Mi}$ nuten, bei $60^{\circ} \mathrm{C}$ etwa 1 Minute und bei über $65^{\circ} \mathrm{C}$ etwa 1 Sekunde. Nach Lyophilisation wird HIV bei $100^{\circ} \mathrm{C}$ für $10 \mathrm{Minu}-$ ten (sog. Trockenhitze) vollständig inaktiviert [56]. Bei niedrigen Temperaturen ist HIV lange stabil: bei $20^{\circ} \mathrm{C}$ beträgt $\mathrm{t} / 2$ etwa $9 \mathrm{~h}$, bei $4^{\circ} \mathrm{C}$ mehrere Monate und unter $-70^{\circ} \mathrm{C}$ unbegrenzt. Bei $-20^{\circ} \mathrm{C}$ findet eine geringe, aber kontinuierlicher Abnahme des Titers infektösen HIVs und Abbau der HIV-RNA statt (abnehmende NAT-Signale; ca. 15.000 Kopien/ml pro Jahr). Proben für forensische Zwecke sollten daher bei einer Temperatur tiefer als $-20^{\circ} \mathrm{C}$ gelagert werden.

Halbwertszeit in Blut und Plasma

In Plasma beträgt die HIV-Halbwertszeit $(\mathrm{t} / 2)$ bei Körpertemperatur etwa $2 \mathrm{Ta}$ ge [45], bei $4^{\circ} \mathrm{C}$ beträgt sie etwa 1 Monat. Folglich wird bei einer Virusmenge von $100.000\left(10^{5}\right)$ Partikeln/ml in einer bei $4{ }^{\circ} \mathrm{C}$ gelagerten Blutkonserve innerhalb von 6 Wochen Laufzeit eine Reduktion um etwa 1,5 Halbwertszeiten stattfinden. In EDTA-Blut und EDTA-Plasma betrug die HIV-RNA-Stabilität (Abnahme $<0,5$ $\log _{10}$ ) bei $4{ }^{\circ} \mathrm{C} 7$ Tage, bei $25^{\circ} \mathrm{C} 3$ Tage und bei $30^{\circ} \mathrm{C} 2$ Tage [57]. Wenn eine humaninfektiöse Dosis (1 HID) etwa 500-1000 $\left(10^{3}\right)$ HIV-Partikel sind, ist auch eine geringe Menge transfundiertes Blut ausreichend, um eine Infektion zu übertragen, auch wenn gelegentlich Ausnahmen vorkommen [58].

Die Infektiosität des HIV-Partikels innerhalb von weißen Blutzellen ist variabel. Es ist davon auszugehen, dass prozessiertes HIV in Lymphozyten rascher inaktiviert wird als im Plasma. Eine Zeit von etwa 2 Tagen ist in Kulturzellen gemessen worden [47], jedoch ist anzunehmen, dass eine Zeit von Wochen bei $4^{\circ} \mathrm{C}$ vergeht, bis intrazelluläres HIV zerstört ist. In dendritischen Zellen kann HIV für Wochen infektionstüchtig bleiben [41]. In lyophilisiertem Plasma oder Faktorenkonzentrat in Gegenwart hoher Proteinkonzentrationen bleibt HIV bei Raumtemperatur jahrelang infektionsfähig.

\subsection{HIV-Infektion und Infektionskrankheit}

HIV kann über die intakte Schleimhaut, ekzematös veränderte oder verletzte Haut bzw. Schleimhaut und durch parenterale Inokulation in den Organismus gelangen. Bei der Übertragung durch Ge- 


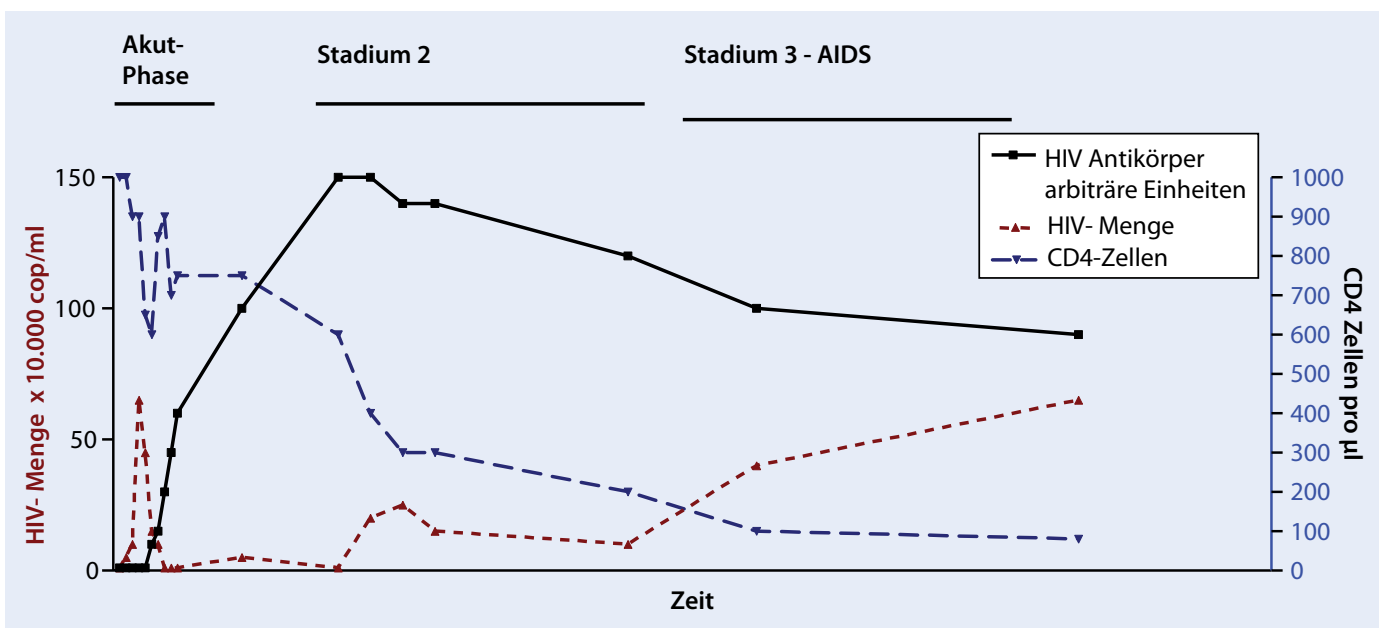

Abb. 4 \ Schematische Darstellung des zeitlichen Verlaufes einer unbehandelten HIV Infektion. Der Maßstab ist anfangs Wochen (Akut-Phase), dann Monate und schließlich Jahre (Stadium 2 und 3). Das Wesentliche an der Virämie ist das Undulieren nach anfänglich ungehemmter HIV-Vermehrung. Die CD4-Zellen fallen über die Zeit ab, auch wenn immer wieder Phasen der Erholung vorkommen. HIV-Antikörper bleiben lebenslang messbar, die Abnahme in Stadium 2 und 3 erfolgt über den Verlust der core-Antikörper (anti-p55, -p24 und -p17). Die Gesamtzeit vom Viruseintritt bis zum Auftreten von AIDS kann ohne Therapie 2 bis 25 Jahre oder länger betragen. Grafik mit freundlicher Genehmigung von Lutz Gürtler

schlechtsverkehr lagert sich HIV zuerst an dendritische Zellen, z. B. Langerhanszellen oder Makrophagen/Monozyten an, und es findet eine präferentielle Vermehrung von Viren statt, die CCR5 als Korezeptor verwenden (R5-Viren) [59]. HIV wird von Makrophagen aufgenommen und dort repliziert [60], wie an MZellen der Mukosa beschrieben [61]. Bei Exposition von Blutzellen ist eine direkte Infektion von T-Helfer-Lymphozyten möglich, so dass R5 und X4 (den CXC4Rezeptor als Korezeptor nutzend) Viren übertragen werden [62]. Eine human-infektiöse Dosis (1 HID) entspricht, wie erwähnt, etwa 500 bis 1000 HIV-Partikeln, wobei für die Infektionsübertragung über die Schleimhaut eine höhere Dosis erforderlich ist als über die Blutbahn, wie z. B. bei Nadelstichverletzungen. Die Mehrzahl der HIV-Neuinfektionen erfolgt über den sexuellen Weg. Ein weiterer epidemiologisch relevanter Weg sind parenteral applizierte Drogen und das Schnupfen von Drogen mit Epistaxis.

HIV lässt sich nach Infektion im regionalen lymphatischen Gewebe innerhalb von etwa 1 bis 2 Tagen nachweisen [63], in den regionalen Lymphknoten innerhalb von etwa 5 bis 6 Tagen und im ganzen Körper verteilt, einschließlich des Nervensystems, innerhalb von etwa 10 bis 14 Tagen, wobei ein Unterschied in der Geschwindigkeit der Verbreitung be- steht, wenn primär Zellen der Tonsillen oder der rektalen Mukosa infiziert wurden [64].

Innerhalb des Organismus können verschiedene Kompartimente unterschieden werden, deren HIV-Konzentrationen nicht miteinander korrelieren. HIV-relevante Kompartimente sind Blut, Zerebrospinal- und Genitalsystem (Ejakulat bzw. Vaginalsekret) $[65,66]$.

Eine Übertragung von HIV über Blut oder Organe einschließlich Knochen ist etwa ab dem 5. Tag nach Infektion des Spenders möglich. Materno-fetale Übertragungen sind ab der 12. Schwangerschaftswoche nachgewiesen worden, finden aber im Wesentlichen ( $>90 \%$ der berichteten Übertragungen) im letzten Trimenon statt, vor allem kurz vor oder unter der Geburt [67]. HIV kann über Muttermilch übertragen werden [68].

Mit Beginn der humoralen Immunantwort gegen HIV nach 3 bis 6 Wochen ist bei der Mehrzahl der Infizierten eine variable klinische Symptomatik $[5,69]$ mit Fieber, Lymphknotenschwellung, Müdigkeit, Abgeschlagenheit, kleinfleckigen, wenig erhabenen Hauteffloreszenzen und/oder gastrointestinalen Symptomen zu beobachten. Diese Symptome sind unspezifisch und kommen auch bei anderen Viruserkrankungen vor, wie z. B. EBV-und CMV-induzierter Mononukleose oder Influenza. Eine akute Neuro- pathie ist im Akutstadium häufig. Die Krankheitssymptome halten 2 bis 6 Wochen an. Es folgt in der Regel eine jahrelange asymptomatische oder wenig symptomatische Phase.

$\mathrm{Zu}$ Beginn der Infektion werden Virustiter im Blut von $10^{5}$ bis zu $10^{9}$, in Ausnahmefällen bis zu $10^{14}$ Genomkopien/ml erreicht (• Abb. 4; [69]), dementsprechend ist das Blut hoch infektiös. Während der asymptomatischen Phase kann der Virustiter bis unter $10^{2}$ Genomkopien/ml absinken; aber auch in dieser Phase sind infizierte Personen über Blut und Genitalsekrete infektiös. Ab etwa 11 Tagen kann HIV-RNA im Blut nachweisbar sein [70], ab der zweiten Woche HIV-DNA in BlutLymphozyten [71]. Auch in weißen Blutzellen von HIV-infizierten LTNP (long term non progressors oder sog. elite controllers) [72], die keine messbare Virämie aufweisen, kann provirale HIV-DNA nachgewiesen werden, wenn Lymphozyten angereichert und stimuliert werden [73-75].

Mit den verfügbaren HIV-Antikörper-Suchtesten lassen sich abhängig von der Immunantwort und dem verwendetem Test ab etwa der 3 . Woche nach Infektion, normalerweise nach 4 bis 5 Wochen, und bei verzögerter Immunantwort nach 8 Wochen, im Plasma HIV-spezifische Antikörper nachweisen (siehe 1.4) $[70,71]$. Zu Beginn der Infektion sind die 
IgM- und IgG-Antikörperspiegel niedrigtitrig und hauptsächlich gegen p24 und die Oberflächenglykoproteine gp120 und gp41 gerichtet. In der Folge, meist innerhalb von 1 bis 3 Wochen, bilden sich hochavide IgG-Antikörper gegen alle HIVProteine. Gegen sehr viele der Epitope von HIV-Proteinen wird auch eine spezifische T-Zell-Antwort induziert [76].

Die frühe Immunantwort beinhaltet wie bei anderen Virusinfektionen auch IgM-Antikörper, die über Monate persistieren können [5]. Ein Teil der Antikörper hat neutralisierende Kapazität, sei es, dass sie gegen gp120, gp41 oder p24/p17 des infizierenden Virus gerichtet sind. Ein hoher Anteil der neutralisierenden Antikörper ist gegen den V3-loop des gp120 gerichtet. Die Antikörper sind stammspezifisch und können die sich im Organismus eines Individuums ausbildenden Quasispezies von HIV dauerhaft nicht ausreichend eliminieren $[25,77,78]$. Unter dem Eliminationsdruck des Immunsystems werden Viren mit variablem V3-loop selektioniert. Der V3-loop ist diejenige Region des gp120-Proteins, in der sehr viele Aminosäurenaustausche (hypervariabel) stattfinden. Eine serologische Subtypdifferenzierung ist nicht möglich, sie kann aber über subtypspezifische Aminosäurensequenzen aus der C2V5-Region erfolgen [8].

Abhängig von der CD4-Zellzahl treten anfangs unspezifische Symptome wie kurze Fieberepisoden, Durchfälle, Abgeschlagenheit, Müdigkeit und Gewichtsabnahme auf (sog. AIDS-related complexARC). Mit zunehmender Immunschwäche, häufig mit CD4-Zellzahlen <300/ $\mu$, verfällt die Kraft der Immunabwehr und es treten opportunistische Infektionen und Neoplasien auf. Typisch für die HIV-Infektion ist ein Verlauf mit Phasen des Wohlergehens gefolgt von Phasen der Krankheit, die häufiger und länger werden $[79,80]$. Die Zeit bis zum Auftreten einer sichtbaren Immunschwäche ist, wie erwähnt, mit 2 bis 25 Jahren (siehe Abb. 4) und länger variabel. In jedem Stadium können, wie angeführt, neurologische und zerebrale Funktionen beeinträchtigt sein.

Häufig auftretende opportunistische Infektionserreger sind Toxoplasma gondii, Cryptosporidium parvum, Pneumo- cystis jirovecii, Mycobacterium tuberculosis und atypische Mykobakterien, Salmonella sp, Pneumokokken, das humane Polyomavirus JC, Zytomegalievirus (CMV) und Herpes simplex-Virus (HSV). Typische Neoplasien unter HIV sind das Kaposi-Sarkom, assoziiert mit dem humanen Herpesvirus Typ 8 (HHV-8), NonHodgkin-Lymphome, z. B. Epstein-BarrVirus (EBV)-assoziiertes B-Zell-Lymphom, und über humanes Papillomvirus (HPV) induzierte Penis-, Anal- und Zervixkarzinome. Bei Jahre dauernder HIV-Infektion beginnt der Marasmus, der nicht therapierte Patienten äußerlich prägt [5]. Eine gleichzeitige Infektion mit Hepatitis C-Virus führt zur schnelleren Progression beider viraler Krankheiten [81-83]. Ein Teil der HIV-Infizierten entwickelt typische atrophe Hautveränderungen oder ein seborrhoisches Ekzem, welches das Infektionsgeschehen äußerlich erkennbar macht. Ebenfalls zu einem frühen Zeitpunkt erkennbar sind Veränderungen auf der Mundschleimhaut mit Retraktion der Gingiva und tiefen parodontotischen Prozessen sowie die Haarleukoplakie am lateralen Rand der Zunge bzw. der Wangenschleimhaut [84].

Autoren von WHO/CDC haben entsprechend dem klinischen Bild und der CD4-Zellzahl die HIV-Infektion in Stadien eingeteilt, die von A1 bis C3 reicht [85]. A heißt asymptomatisch, B bedeutet geringe Symptome bis ARC und C AIDSdefinierende Erkrankung. Im Stadium 1 liegt die CD4-Zellzahl über 500, in 2 zwischen 499 und 200 und in 3 unter 200 pro $\mu$ Plasma.

\subsection{Epidemiologie der HIV-Infektion}

Die Ausbreitung von HIV hat nach heutiger Kenntnis zu Beginn des 20. Jahrhunderts begonnen $[4,86]$. HIV-1 Gruppe M und Gruppe O sind etwa um 1920, HIV1 Gruppe $N$ etwa ab 1960 [23, 33] durch zoonotische Übertragungen des SIVcpz vom Schimpansen (Pan troglodytes troglodytes) in West-Zentralafrika entstanden. HIV-2 wurde etwa um 1940 in Westafrika zoonotisch von Rußkopf-Mangaben (Cercopithecus atys) übertragen [87]. Molekulargenetische Analysen deuten darauf hin, dass HIV-1 wahrscheinlich 1966 nach Hai- ti exportiert wurde und von dort ca. zwei Jahre später nach Nordamerika gelangte $[4,88]$. Ungefähr seit Mitte der 1980er Jahre verbreiteten sich die verschiedenen HIV-1 M-Subtypen zu einer globalen Pandemie. Dagegen blieb anfangs HIV-2 wahrscheinlich aufgrund seiner im Vergleich zu HIV-1 deutlich geringeren Infektiosität auf Westafrika beschränkt. Ausgehend von nach Portugal und Frankreich exportierten Fällen vermutlich ab Mitte der 1960er Jahre ist auch eine niedrigprävalente Verbreitung von HIV-2 insbesondere in Europa, Südamerika und Asien dokumentiert.

Für das Jahr 2013 wird geschätzt, dass weltweit etwa 35 Millionen Menschen mit HIV infiziert waren [89]. Seit 1999 nimmt dabei die Zahl von Neuinfektionen kontinuierlich ab und lag 2012 bei geschätzten 1,9 Millionen. Etwa drei Viertel der HIV-Infizierten leben in Subsahara-Afrika, und auch etwa zwei Drittel der Neuinfizierten stammen aus dieser Region. Die am stärksten betroffenen Länder mit der höchsten HIV-Prävalenz bei 15 - bis 49-Jährigen sind Swasiland (ca. 27\%), Lesotho (ca. $23 \%$ ) und Botswana (ca. $23 \%$ ).

Deutschland. Die deutschen Daten zur HIV-Epidemie beruhen im Wesentlichen auf der Meldepflicht. Der Nachweis einer HIV-Infektion ist nach $₫ 7$ Abs. 3 des Infektionsschutzgesetzes [IfSG] nichtnamentlich meldepflichtig. Die Meldung erfolgt direkt an das Robert Koch-Institut (RKI). Primär meldepflichtig ist das diagnostizierende Labor (auch der diagnostizierende Blutspendedienst), welches dem einsendenden Arzt einen Durchschlag des Meldebogens schickt. Der einsendende Arzt ist verpflichtet, dem Labor nicht zur Verfügung stehende demografische, anamnestische und klinische Angaben auf dem Meldebogen zu ergänzen und den so ergänzten Meldebogen direkt an das RKI zu senden. Um bei diesem Verfahren Mehrfachmeldungen ein und desselben Patienten zu erkennen, wird eine die Anonymität wahrende fallbezogene Verschlüsselung verwendet ( $\$ 10$ Abs. 2 IfSG).

Für die Beschreibung der HIV-Epidemie werden darüber hinaus das AIDSFallregister, die AIDS- und HIV-Todesfallberichte an das RKI, die Todesursachen-Statistik der statistischen Landesäm- 
Tab. 2 HIV-Neudiagnosen und Übertragungswege in verschiedenen europäischen Regionen 2012 (http://www.euro.who.int/_data/assets/pdf_file/0018/235440/e96953.pdf)

\begin{tabular}{llllll}
\hline $\begin{array}{l}\text { Region nach WHO } \\
\text { und EU/EEA }\end{array}$ & $\begin{array}{l}\text { WHO Europäi- } \\
\text { sche Region }\end{array}$ & $\begin{array}{l}\text { WHO West- } \\
\text { europa }\end{array}$ & $\begin{array}{l}\text { WHO Mittel- } \\
\text { europa }\end{array}$ & $\begin{array}{l}\text { WHO Ost- } \\
\text { europa }\end{array}$ & EU/EEA \\
\hline $\begin{array}{l}\text { Anzahl meldender } \\
\text { Länder/Länder }\end{array}$ & $51 / 53$ & $23 / 23$ & $15 / 15$ & $13 / 15$ & $30 / 31$ \\
\hline $\begin{array}{l}\text { Anzahl gemeldeter } \\
\text { HIV-Neudiagnosen }\end{array}$ & 55.494 & 27.315 & 3.715 & 24.464 & 29.381 \\
\hline $\begin{array}{l}\text { HIV-Neudiagno- } \\
\text { sen/100.000 Bevöl- } \\
\text { kerung }\end{array}$ & 7,8 & 6,6 & 1,9 & 22 & 5,8 \\
\hline $\begin{array}{l}\text { Anteil 15-24-Jäh- } \\
\text { riger }\end{array}$ & $10,3 \%$ & & & & \\
\hline $\begin{array}{l}\text { Verhältnis Männer/ } \\
\text { Frauen }\end{array}$ & $2,1: 1$ & $9,8 \%$ & $15,4 \%$ & $10,1 \%$ & $10,6 \%$ \\
\hline Übertragungsweg & $3,1: 1$ & $4,5: 1$ & $1,4: 1$ & $3,2: 1$ \\
\hline Heterosexuell & $45,6 \%$ & $35,3 \%$ & $24,6 \%$ & $60,2 \%$ & $33,8 \%$ \\
\hline MSM & $22,8 \%$ & $41,7 \%$ & $26,2 \%$ & $1,2 \%$ & $40,4 \%$ \\
\hline $\begin{array}{l}\text { i.v. Drogenge- } \\
\text { brauch }\end{array}$ & $17,8 \%$ & $5,1 \%$ & $7,3 \%$ & $33,6 \%$ & $6,1 \%$ \\
\hline Unbekannt & $12,3 \%$ & $17 \%$ & $36,9 \%$ & $3,2 \%$ & $18,7 \%$ \\
\hline aSchließt in den Regionen lebende Personen aus Subsahara-Afrika ein (12\%). & & \\
\hline
\end{tabular}

ter sowie Verkaufsdaten zur antiretroviralen Therapie aus Apothekenabrechnungszentren herangezogen.

Die zur Verfügung stehenden Surveillance-Instrumente liefern jeweils nur Daten zu einem begrenzten Ausschnitt der HIV-Epidemie. Daher erstellt das RKI regelmäßig Schätzungen zum Verlauf der HIV-Epidemie, die die verfügbaren Daten und Informationen aus den verschiedenen Quellen berücksichtigen. Die Bestimmung der Anzahl der HIV-Neuinfektionen pro Zeiteinheit (HIV-Inzidenz) ist anhand der gesetzlichen Meldedaten nicht möglich, denn die Meldungen über HIVNeudiagnosen erlauben keine direkten Rückschlüsse auf die Infektionszeitpunkte. Aufgrund dessen können die HIV-Inzidenz und die HIV-Prävalenz nicht direkt gemessen werden, sondern nur mit Hilfe von Modellrechnungen abgeschätzt werden.

Die geschätzte Zahl von HIV-Neuinfektionen hat sich im Zeitverlauf von Spitzenwerten Mitte der 1980er Jahre zunächst in allen Altersgruppen bis zum Ende der 1990er Jahre deutlich reduziert. Von 2000 bis ca. 2005 erfolgte dann wieder ein deutlicher Anstieg der HIV-Infektionen mit einer Plateaubildung ab 2006. Die Gesamtzahl der HIV-Neuinfektionen in Deutschland im Jahr 2013 wurde auf 3.200 (95\% KI: 3.000-3.400) ge- schätzt [90-92]. Die Entwicklung in den verschiedenen Betroffenengruppen war dabei sehr unterschiedlich. Von der geschätzten Gesamtzahl der HIV-Neuinfektionen in 2013 waren etwa 2.400 (75\%) Männer, die Sex mit Männern haben (MSM). Etwa 360 Frauen (11,3\%) und 190 Männer (5,9\%) haben sich auf heterosexuellem Weg in Deutschland infiziert. Darüber hinaus haben sich etwa $300(9,4 \%)$ Personen beim intravenösen Drogenkonsum infiziert (IVD). Die Entwicklungstrends in den drei Hauptbetroffenengruppen in Deutschland verliefen unterschiedlich: Bei MSM und IVD wurde etwa zeitgleich Mitte der 1980er Jahre ein erster Infektionsgipfel erreicht. Danach ging die Zahl der HIV-Neuinfektionen in beiden Gruppen bis Anfang der 1990er Jahre deutlich zurück. Bei IVD hat sich dieser rückläufige Trend seit Anfang der 1990er Jahre bis 2010 kontinuierlich fortgesetzt. In der letzten Dekade seit 2001 blieb die Zahl der HIV-Neuinfektionen bei IVD auf niedrigem Niveau weitgehend konstant. Auch in der Gruppe der MSM erfolgten in den 1990er Jahren deutlich weniger Infektionen. In der Zeit zwischen 2000 und 2006 wurde allerdings wieder eine deutliche Zunahme von HIV-Infektionen beobachtet, die dann ab 2006 in ein neues, deutlich höheres Plateau übergeht. Die geschätzte HIV-Inzidenz bei
MSM in Deutschland war im Jahr 2013 in der Altersgruppe der 25- bis 29-jährigen Männer mit 19 HIV-Neuinfektionen pro 100.000 männlicher Einwohner am höchsten - das entspricht bei angenommenen $3 \%$ MSM unter erwachsenen Männern etwa 6 pro 1.000 MSM. Die Zahl der Personen, die sich in Deutschland auf heterosexuellem Wege infizierten, stieg im Verlauf der Epidemie deutlich langsamer an als in den beiden Gruppen MSM und IVD. In den Jahren seit 2005 blieb sie auf einem etwa gleichbleibenden Niveau. Es wurde zu keiner Zeit ein initialer Spitzenwert wie bei MSM und IVD erreicht. Die HIV-Epidemie in dieser Gruppe wurde im Wesentlichen über sexuelle Kontakte zu IVD, MSM und im Ausland mit HIV infizierten Personen gespeist; eigenständige heterosexuelle Infektionsketten sind für die Ausbreitung der HIV-Epidemie von geringer Bedeutung.

Betrachtet man die gemeldeten Neuinfektionen, so zeigten sich große regionale Unterschiede. Insbesondere in Ballungsgebieten (u. a. Rhein-Ruhr, Rhein-Main) und Großstädten war die Inzidenz der Neudiagnosen sehr viel höher als in den übrigen Regionen. Die höchsten Inzidenzen mit 15 HIV-Neudiagnosen/100.000 Einwohner wurden für Köln, Frankfurt und Berlin ermittelt [92].

Im Jahr 2012 wurde bei HIV-Neudiagnosen fast ausschließlich HIV-1 diagnostiziert, lediglich $0,3 \%$ wurden durch HIV2 verursacht. Der in Deutschland vorherrschende Subtyp ist HIV-1 M:B (etwa $85 \%$ ), wie in den Ländern Dänemark, Niederlande und Luxemburg [93].

Europa. In 2012 wurden ca. $30.000 \mathrm{HIV}$ Neudiagnosen in der Europäischen Union (EU) und dem Europäischen Wirtschaftsraum (EEA) gemeldet. Die meisten Neudiagnosen wurden in Litauen, Estland, Belgien, dem Vereinigten Königreich und Luxemburg gemeldet [94]. In 2012 lag das Verhältnis von Männern zu Frauen bei Neuinfektionen bei 3,2:1. Der Anteil der HIV-Neudiagnosen ist seit 2006 relativ stabil. Jedoch ist der Anteil der Infektionen, bei denen Sexualkontakte unter Männern genannt wurden, seit 2006 um $11 \%$ auf jetzt $40,4 \%$ angestiegen. Der Anteil der i.v. Drogengebraucher mit Neudiagnosen sank in demselben Zeitraum um 
$7 \%$. In Osteuropa stehen i.v. Drogengebrauch und heterosexuelle Übertragungswege bei den HIV-Neudiagnosen im Vordergrund (siehe $\bullet$ Tab. 2).

Hinsichtlich der molekularepidemiologischen Daten zeigt sich, dass HIV-1 Gruppe M-Subtypen eine unterschiedliche regionale Prävalenz haben. In Westeuropa, wie in der übrigen westlichen Welt, ist die Infektion mit HIV-1 M:B prädominant. Die Prävalenz von HIV-1-Subtypen und von HIV-2 in den europäischen Ländern spiegelt die historische Verbindung dieser Staaten zu den entsprechenden Endemiegebieten in Afrika wider [12, 17, 93]. In Belgien war die Hälfte der Infektionen durch HIV-1 M:A (Ursprung Kongo-Kinshasa) verursacht. In England und Frankreich sind alle Subtypen zu finden, und in Portugal und Frankreich ist neben HIV-1 M:B und weiteren M-Subtypen und Gruppen auch HIV-2 prävalent $[23,95]$. Ungewöhnlich für Europa war das Auftreten einer HIV-1-M:F-Epidemie in Rumänien; dieser Subtyp wurde aus Angola eingebracht [96]. Die baltischen Staaten und Osteuropa haben eine hohe HIV-1-Prävalenz und -Inzi$\operatorname{denz}$ (• Tab. 2); in Westrussland ist der prädominante HIV-Stamm HIV-1 M:A/B (CRF03_AB) [97].

Afrika. Afrika ist der Kontinent, der am schwersten von der HIV-Infektion betroffen ist. In Afrika leben ca. 25 Millionen Menschen mit HIV, davon ca. 22 Millionen in Subsahara-Afrika [89]. Die geschätzte HIV-Prävalenz in Afrika variiert stark und liegt zwischen 0,1\% in Ägypten und Marokko und etwa $27 \%$ in Swaziland. HIV wird in Afrika hauptsächlich heterosexuell übertragen; Sexarbeit und sexuelle Gewalt tragen deutlich zu den Übertragungen bei. Etwa ein Drittel der Infizierten erhielt 2013 eine antiretrovirale Therapie [89].

In Afrika zirkulieren alle HIV-1 MSubtypen und HIV-2; letzteres insbesondere in Guinea-Bissau, Senegal, Elfenbeinküste und angrenzenden Staaten sowie in Angola und Mosambik. Im Süden Afrikas herrscht HIV-1 M:C vor, im Westen Afrikas HIV-1 M:A und das rekombinante HIV-1 M:A/G (CRF02_AG) und in Äthiopien HIV-1 M:C. Zentralafrika, das sog. Kongo-Becken, beherbergt al- le HIV-1-Subtypen, und in Ländern, die an den Golf von Guinea angrenzen, treten auch HIV-1 Gruppe O- und N-Viren auf [12, 23]. Die zwei mit HIV-1 Gruppe P infizierten Patienten stammen aus Kamerun [11]. Die HIV-Prävalenz kann in ländlichen Regionen von Zentralafrika nur wenige Promille erreichen und in städtischen Regionen bis $30 \%$ [98]. HIV-1 M:C ist mit einem Anteil von 30 bis $36 \%$ der weltweit häufigste Subtyp; seine schnelle Verbreitung wird mit der gesteigerten Virus-Produktion im Menschen unter dem Einfluss von Sexualhormonen in Verbindung gebracht [99].

Asien. In Asien leben ca. 1,7 Millionen Menschen mit HIV; etwa $50 \%$ erhalten eine antiretrovirale Therapie. Die Anzahl der HIV-Neudiagnosen ging zwischen 2001 und 2012 um ca. $26 \%$ zurück. Bei einer insgesamt eher niedrigen HIV-Prävalenz in der Region sind Kambodscha, China und Indien die Länder mit dem höchsten Anteil an HIV-Neudiagnosen. Die Epidemie ist konzentriert auf bestimmte Gruppen mit hohem Expositionsrisiko wie MSM, Sexarbeiter, Drogengebraucher und Transsexuelle [89]. In Asien spiegelt die HIV-Verbreitung die Kontakte mit Afrika und Nordamerika wider. In Thailand wurde HIV$1 \mathrm{M}: \mathrm{A} / \mathrm{E}$ (CRF01_AE) durch heterosexuellen Geschlechtsverkehr und HIV-1 M:B in der Population der Drogenkonsumenten (spezifischer Subtyp Bt) verbreitet [100]. Im westlichen Indien hat die Epidemie von HIV-2 vom ehemals portugiesischen Goa aus begonnen [101]. Die HIV-1Epidemie in Indien startete von Rückkehrern aus Ost- und Südafrika und war im Wesentlichen durch HIV-1 M:C bedingt [102]. In China finden sich HIV-1 M:A, $\mathrm{B}, \mathrm{C}$ und A/E (CRF01_AE), wobei sich ein eigener rekombinanter $\mathrm{M}: \mathrm{B} / \mathrm{C}$-Subtyp (CRF07_BC und CRF08_BC) schneller als die anderen Subtypen ausbreitet [17, 103]. In China ist ein neues rekombinantes HIV beschrieben worden (CRF59_01B), welches aus dem A/E-(CRF01_AE) und B-Subtyp entstanden ist $[15,104]$, was ein weiterer Hinweis auf die kontinuierliche Evolution von HIV-1 Gruppe M im Menschen ist.
Australien. In Australien hat die Anzahl der HIV-Neudiagnosen seit 2003 um ca. $26 \%$ zugenommen und lag 2012 bei 5,4/100.000 Einwohner. Der Hauptübertragungsweg sind sexuelle Kontakte unter Männern [105]. In Australien ist hauptsächlich HIV-1 M:B verbreitet, weitere Subtypen wurden besonders aus Asien eingeführt. Ein anfangs verbreiteter Subtyp B-Stamm hatte einen Nef-Defekt und eine geringere Pathogenität [106].

Nordamerika. In den USA werden jährlich etwa 50.000 HIV-Neudiagnosen gemeldet; die Prävalenz beträgt ca. 0,23\% [107]. Ca. 1,1 Million Menschen leben dort mit HIV, von diesen sind $25 \%$ Frauen. Der Hauptübertragungsweg sind sexuelle Kontakte unter Männern. Ungefähr ein Drittel aller HIV-Infizierten erhält eine antiretrovirale Therapie [108].

In Kanada wurde 2012 bei 2.062 Personen eine HIV-Infektion neudiagnostiziert, die niedrigste Zahl seit Erfassung der Neudiagnosen 1996. Auch in Kanada sind MSM die Hauptbetroffenengruppe. Vorherrschend ist HIV-1 M:B; weitere Subtypen sind aus Afrika, Asien und Südamerika eingeführt worden. Der Subtyp $B$ hat insofern Bedeutung, weil die meisten der in den USA entwickelten Teste auf Subtyp B-Erkennung basieren und deswegen diesen HIV-Subtyp am sensitivsten erfassen.

Die Zahl der HIV-1 Gruppe O-Infizierten ist in den USA und Kanada unter 20 $[22,98]$. Die Zahl der HIV-2-Infizierten in den USA wird mit 166 angegeben und ist ansteigend - ein Teil der HIV-2-Infizierten stammt aus Westafrika [109].

Südamerika. In Lateinamerika leben ca. 1,3 bis 1,9 Millionen Menschen mit HIV. In Belize, Guyana und Surinam liegt die geschätzte HIV-Prävalenz über $1 \%$ [89]. Neben HIV-1 M:B (und speziell dem brasilianischen Subtyp Bb) sind HIV-1 M:A, A/E (CRF01_AE), C und F [96] und weitere Rekombinanten [16] dort und in den Nachbarländern verbreitet. In Argentinien zirkulieren zwei weitere rekombinante Stämme aus den Subtypen B und F: CRF12_BF und CRF17_BF [110]. 


\subsection{HIV-Nachweismethoden}

Grundsätzlich können zwei Arten des Nachweises unterschieden werden: Antikörper- und Virusnachweis. HIV-RNA kann etwa 11 Tage nach Infektion im Blut über die NAT nachgewiesen werden.

\subsubsection{Antikörper}

Als primärer Nachweis einer HIV-Infektion werden Antikörpersuchteste mit anschließender Bestätigung reaktiver Testergebnisse verwendet. Neben dem ELISA (enzyme linked immunosorbent assay) - oder Varianten dieses Tests - werden auch Partikelagglutinationsteste verwendet. Zugelassene ELISA enthalten Antigene von HIV-1 M, vorzugsweise HIV$1 \mathrm{M}: \mathrm{B}$, Gruppe O und HIV-2. Herstellerspezifisch finden sich zusätzlich Antigene aus der reversen Transkriptase und aus dem p24-Protein [111-113]. Abhängig von der Immunantwort und dem Antikörpertiter kann eine Infektion serologisch bereits nach 3 Wochen, meist jedoch nach 4 bis 5 Wochen nachgewiesen werden [114]. Selten können HIV-Infizierte mit einer durch HIV bedingten vollkommenen Immunsuppression anti-HIV-negativ sein - sie haben jedoch HIV-typische klinische Symptome und messbare Virustiter im Blut [115].

Bestätigungstest (Western Blot, Immunoblot)

Da der ELISA wegen des Nachweises auch geringer Antikörpermengen auf höchste Sensitivität eingestellt ist, kommen falsch positive Resultate vor, vor allem wenn Immunkomplexe im Serum vorhanden sind, z. B. wenn Infektionen mit anderen Erregern ablaufen, nach Impfungen oder wenn es zu einer starken Stimulierung des Immunsystems kommt. Zudem wurde über falsch positive Ergebnisse bei Personen mit Autoimmunerkrankungen, Allergikern und Schwangeren berichtet. Fehler in der Präanalytik können zu falsch positiven Suchtesten führen, z. B. bei nicht vollständiger Gerinnung.

Als serologischer Bestätigungstest ist in Deutschland der Immuno-/Western Blot eingeführt, der jedoch in der Frühphase der HIV-Infektion eine geringere Sensitivität als Antikörpersuchteste bzw. p24-Antigenteste aufweist.
Nur wenn die Kriterien für einen positiven Immuno-/Western Blot oder für eine NAT mit > $1.000 \mathrm{Kopien} / \mathrm{ml}$ vorliegen, kann von einer bestätigt positiven HIVInfektion ausgegangen werden [116]. Liegen beide Testergebnisse - Antikörpersuchtest reaktiv und NAT positiv - vor, kann der Immunoblot zur Bestätigung entfallen und ein HIV-Infizierter nach Antikörpertestung und NAT über seinen Status informiert und einer spezifischen Betreuung und Therapie zugeführt werden [116].

Da die Mitteilung eines positiven HIVBefundes für die/den Infizierte/n weitreichende Konsequenzen hat, besteht die Empfehlung, bei einem positivem Resultat in der Erstuntersuchung eine zweite unabhängig genommene Blutprobe zu untersuchen und gleichzeitig die Menge viraler Genome (viral load) über eine NAT zu bestimmen, um eine eventuelle Therapiebedürftigkeit zu erkennen [116, 117].

\subsubsection{Virusnachweis}

Die kulturelle Anzucht von HIV dauert bis zu 6 Wochen, gelingt häufig nicht und ist kostenintensiv. Für die Diagnostik in Blutspendediensten ist sie ohne Bedeutung.

\section{p24-Antigen}

Das p24-Protein bildet das innere Kapsid. In einem Viruspartikel sind etwa 2.000 p24-Moleküle vorhanden [118]. Der p24-Nachweis erfolgt mit einer Kombination von polyklonalen bzw. monoklonalen Antikörpern nach dem Prinzip des Sandwich-ELISA und erlaubt, bei einer Sensitivität von $10 \mathrm{pg} / \mathrm{ml}$ (entspricht einer Menge von etwa $10^{5}$ Virus-Partikeln/ml Blut) HIV nachzuweisen. Singuläre p24-Antigenteste oder kombinierte Antigen/Antikörperteste ( $\operatorname{sog} 4$. Generationsteste) sind zugelassen und kommerziell erhältlich $[114,119]$.

Etwa 60 bis $80 \%$ der Serokonversionen verlaufen ohne nachweisbare p24-Antigenämie [120]. Im Verlauf der Infektion kann p24 frei oder an Partikel gebunden im Plasma vorhanden sein und erreicht bei AIDS-Patienten teilweise hohe Spiegel. Es besteht keine direkte Korrelation zwischen der im Plasma über die NAT gemessene HIV-Partikelzahl und dem p24Antigengehalt, da p24 ohne Virusnukleinsäure von infizierten Zellen abgegeben wird. Auch ein reaktives p24-Antigentestergebnis muss abgeklärt werden. Geeignete Teste sind Blocking/Neutralisationsteste oder bevorzugt die NAT [116]. Über die meisten HIV-1 p24-Antigenteste wird auch das HIV-2 p25-Antigen erkannt, teils jedoch mit verminderter Sensitivität.

Die Untersuchung von Blutspenden auf p24-Protein zusätzlich zu den HIVAntikörpern ist in Deutschland nicht verpflichtend eingeführt worden [121]. Der p24-Antigentest ist in den USA durch die NAT ersetzt worden. Es steht dem Blutspendedienst offen, kombinierte HIVAntigen-/Antikörperteste zu verwenden; die NAT ist dennoch durchzuführen.

NAT - Nukleinsäure-Amplifikations-Technologie

Die HIV-Infektion kann über den Nachweis der proviralen DNA aus dem Zellkern oder des viralen RNA-Genoms aus Plasma erfolgen. Für die Untersuchung der Virusmenge und der HIV-Präsenz in Blutspenden wird die RNA aus dem Viruspartikel aus Plasma extrahiert. Der Genomnachweis kann entweder über die direkte Amplifikation von definierten Zielsequenzen oder über den Einsatz von Sonden mit anschließenden Signal-Amplifikationsverfahren erfolgen. Mit der NAT lassen sich je nach Ausgangsmaterial und Ansatz zwischen 40 und 100 Genomäquivalente pro ml Plasma in der Einzelspende nachweisen [74]. Ein Genomäquivalent entspricht 1,7 $\pm 0,1 \mathrm{IU}$ (international units) [122]. Durch Konzentration der Viruspartikel z. B. durch Ultrazentrifugation oder andere Verfahren kann HIV aus gepooltem Plasma angereichert werden [123]. Für die Qualitätskontrolle und die Quantifizierung stehen Standardmaterialien zur Verfügung [124-126].

Die NAT von kommerziell erhältlichen Testen ist mit Primern, die stringent an HIV-1 M:B-Nukleinsäure binden, entwickelt worden, deswegen werden mit wenigen Ausnahmen Viren des Typs HIV-1 M:B mit der höchsten Sensitivität nachgewiesen. Je weiter eine Nukleinsäuresequenz von HIV-1 M:B abweicht, desto geringer wird die Sensitivität. Je nach Test und Zielsequenz, z. B. gag oder LTR bzw. Integrase (IN), werden nur HIV-1 der Gruppe M oder auch HIV-1 der Gruppe $\mathrm{M}, \mathrm{N}, \mathrm{O}$ und $\mathrm{P}$ nachgewiesen $[23,127-$ 130]. Bei Berücksichtigung der geneti- 
schen Variabilität des HIV-Genoms ist es vorteilhaft, und deswegen für Deutschland seit 2015 vorgeschrieben, Amplifikationsverfahren mit sog. dual target, d. h. zwei Amplifikationsbereichen im HIVGenom, zu verwenden [131-133].

Für das Testen von Blutspenden mit einer kommerziellen NAT werden in Deutschland derzeit die Teste von wenigen Herstellern verwendet. In mehreren Blutspendediensten und bei Herstellern von Plasmaderivaten sind seit 1996 eigene Testverfahren zur Amplifikation von HIV entwickelt worden, sog. home made- oder in-house-Assays [123, 130, 134]. Wenn die Testung ausreichend sensitiv ist, $z$. B. nach einem Ultrazentrifugationsschritt, kann sie auch an sog. Minipools von bis zu 96 Plasmaproben durchgeführt werden [71, 123]. Um bei der NAT Kontaminationen zu vermeiden, sind vollautomatische Verarbeitungssysteme etabliert worden [135]. HIV-2-RNA kann über real-time PCR (Polymerase-Ketten-Reaktion) nachgewiesen werden [136]. Für den quantitativen HIV-2-NAT-Nachweis sind seit 2012 kommerzielle Teste vorhanden [38] sowie zur Qualitätskontrolle und Quantifizierung ein internationaler Standard für HIV-2 [137].

\section{Blut- und Plasmaspender}

\subsection{Prävalenz und Inzidenz bei Spenderkollektiven}

Jedes Jahr werden in Deutschland ca. 7,5 Millionen Blut- und Plasmaspenden von ca. 3 Millionen Spendern untersucht. Dabei werden insgesamt ca. 100 HIV-Infektionen identifiziert und an das RKI gemeldet. Die HIV-Prävalenz unter den Neuspendern ist seit 2008 weitgehend stabil und lag 2012 bei 6,4/100.000. Bei den Serokonversionen unter Mehrfachspendern zeichnet sich in demselben Zeitraum jedoch ein ansteigender Trend ab: 2,6/100.000 Mehrfachspender im Jahr 2008 und 3,3/100.000 Mehrfachspender im Jahr $2012[138,139]$. Dieser Anstieg ist nahezu ausschließlich auf eine Zunahme der HIV-Infektionen unter männlichen Mehrfachspendern zurückzuführen. Die meisten dieser Spender haben sowohl einen reaktiven Antikörpertest als auch eine positive NAT. Je- des Jahr werden jedoch einzelne Spender mit ganz frischen Infektionen identifiziert, bei denen nur HIV-Genom in der NAT gefunden wird und noch keine Antikörper messbar sind; im Jahr 2012 waren es 4 . Seit Jahren ist die Mehrzahl der HIV-infizierten Spender männlich (83\%) und zwischen 24 und 45 Jahre alt. Von etwas mehr als $40 \%$ liegt eine Angabe zum möglichen Übertragungsweg vor. Nahezu in allen Fällen lag eine sexuelle Exposition vor, zu knapp der Hälfte der infizierten Männer wurden sexuelle Kontakte unter Männern als wahrscheinlichster Infektionsweg angegeben. Fast alle Spender (MSM und Heterosexuelle) wären bei Angabe ihrer Exposition nicht zur Spende zugelassen worden. In den vorangegangenen Jahren fiel ein deutlich höherer Anteil von HIV-Infizierten bei Plasmaspendern gegenüber den Vollblutspendern auf. Diese Differenz wird insbesondere bei Mehrfachspendern zunehmend größer. Während die HIV-Inzidenz bei Mehrfach-Vollblutspendern zwischen 2009 und 2012 von 1,8 auf 2,8 Serokonversionen/100.000 Spender anstieg, erhöhten sich die Werte für Mehrfach-Plasmaspender von 4,7 auf 8,4 Serokonversionen/100.000 Spender. Die Gründe hierfür sind unklar. Möglicherweise spielt die Lage der Plasmaspendezentren in Städten eine Rolle ebenso wie der erhöhte Anteil junger männlicher Spender. Der beschriebene Trend ist in anderen Ländern nicht zu sehen [140].

\subsection{Definition von Ausschlusskriterien}

Die Zulassung zur Blutspende ist in den Richtlinien zur Gewinnung von Blut und Blutbestandteilen und zur Anwendung von Blutprodukten (Hämotherapie) geregelt [141]. Kriterien für einen dauerhaften Ausschluss bzw. eine zeitlich befristete Rückstellung von der Spende unter dem Aspekt einer HIV-Übertragung sind definiert worden. Von der Spende dauerhaft ausgeschlossen werden:

- Personen mit einer nachgewiesenen HIV-Infektion,

- Personen, die Drogen konsumieren und Medikamente missbräuchlich zu sich nehmen,
- Personen, deren Sexualverhalten ein gegenüber der Allgemeinbevölkerung deutlich erhöhtes Übertragungsrisiko für durch Blut übertragbare schwere Infektionskrankheiten, wie HBV, HCV oder HIV bergen:

- heterosexuelle Personen mit sexuellem Risikoverhalten, z. B. Geschlechtsverkehr mit häufig wechselnden Partnern,

- Männer, die Sexualverkehr mit Männern haben (MSM),

- männliche und weibliche Prostituierte.

Zeitlich von der Spende zurückgestellt werden Personen,

- die aus einem Gebiet eingereist sind, in dem sie sich kontinuierlich länger als 6 Monate aufgehalten haben, in dem sich HBV-, HCV-, HIV- oder HTLV-1/-2-Infektionen vergleichsweise stark ausgebreitet haben,

- die intimen Kontakt mit Personen hatten, die einer Gruppe mit erhöhtem Infektionsrisiko für $\mathrm{HBV}, \mathrm{HCV}$, HIV und/oder HTLV-1/-2 angehören (s. oben),

- die Tätowierungen oder Durchbohrungen der Haut und Schleimhaut zur Befestigung von Schmuck haben.

Aus wissenschaftlicher Perspektive erscheint es gerechtfertigt, für ein risikobehaftetes Verhalten, das geändert werden kann, eine zeitlich befristete Rückstellung durchzuführen. Daher wird aktuell national und international intensiv diskutiert, ob der lebenslange Ausschluss von MSM und Sexarbeitern abgeschafft und stattdessen eine befristete Rückstellung nach letztem Sexualkontakt unter Männern bzw. nach letzter Sexarbeit angeordnet werden kann [142-144].

\subsection{Spendertestung und Aussagekraft}

\subsubsection{HIV-Antikörpertest}

Die Untersuchung einer Spende erfolgt mit einem in Europa nach MPG (Medizinproduktegesetz) in Verbindung mit der IVD (in vitro-Diagnostik)-Richtlinie zugelassenen Antikörpersuchtest. In Deutschland verwendete Teste erkennen Antikörper gegen alle bekannten HIV- 
1-Gruppen und HIV-2. Einem reaktiven Suchtest muss ein serologischer Bestätigungstest oder ein Nukleinsäurenachweis-Test folgen. Eine zweite Blutabnahme ist bei positivem Ausfall zur Verifizierung der HIV-Infektion erforderlich (siehe 1.4) [116]. Bis zur Abklärung des Ergebnisses wird die Spende ausgesondert und gegebenenfalls für weitere Untersuchungen asserviert. Der Spender wird bis zur Abklärung gesperrt [117]. Nach den bisher vorliegenden Erkenntnissen ist die überwiegende Anzahl der reaktiven Suchteste bei Blutspendern unspezifisch, d. h. falsch positiv und nicht auf eine HIV-Infektion zurückzuführen, sondern hat andere Ursachen, $z$. B. vorhandene Immunkomplexe (siehe 1.4).

\subsubsection{Nachweis von HIV-RNA über NAT}

Durch Einsatz der NAT kann das diagnostische Fenster, das über den Antikörpernachweis zwischen 3 und 6 Wochen beträgt, verkürzt werden. Abhängig von der Höhe der Virämie, der Sensitivität des verwendeten Verfahrens und dem infizierenden HIV kann eine Infektion ab etwa 11 Tagen nachgewiesen werden (siehe 1.4). Die HIV-NAT ist auch bei Nicht-HIV-1 M:B sensitiv. Referenzmaterial zum Nachweis verschiedener HIV-1Genotypen ist erhältlich [126].

Der Einsatz der NAT ist trotz des hohen Arbeits- und Kostenaufwandes indiziert, denn die Mehrzahl der durch zelluläre Blutkomponenten möglichen HIVÜbertragungen der letzten Jahre (nach Ausschluss der Spenden von HIV-Antikörper-positiven Spendern) ist über die NAT verhindert worden [131-133, 145148].

Kosten-Nutzen-Kalkulation: Wie erwähnt ist aufgrund der hohen Kosten der NAT und der derzeit niedrigen Inzidenz in Blutspenden der finanzielle Aufwand für das zusätzliche Eliminieren einer HIV-infektiösen, aber noch HIV-Antikörper-negativen Spende hoch, jedoch gerechtfertigt. Der Aufwand beträgt geschätzt etwa 7,5 Mill. $€$ pro entdeckter und eliminierter HIV-infektiöser Spende. Die HIV-NAT in Blutspenden ist in Deutschland seit Frühjahr 2004 eingeführt [146].

Nachdem in mehreren Fällen NATTeste mit nur einer Primerbindungsre-
gion-Erkennung HIV mit Mutationen in dieser Region nicht erkannt haben, wurde zur Erhöhung der Sicherheit die Erkennung von mindestens zwei Zielregionen (dual target-NAT) für das Spenderscreening verbindlich angeordnet $[132,133]$.

Von einer bestätigt HIV-positiven Spende sollten Plasma und, falls noch möglich, Lymphozyten isoliert und tiefer als $-20^{\circ} \mathrm{C}$ eingefroren werden, damit dieses Material für die Abklärung von Übertragungen durch frühere Spenden auf Empfänger zur Verfügung steht. Über die Nukleinsäure-Sequenz-Analyse in verschiedenen Genomabschnitten kann ein ursächlicher Zusammenhang der HIV-Übertragung abgeklärt werden $[117,149,150]$.

\subsection{Spenderbefragung}

Gemäß den Hämotherapie-Richtlinien sind durch einen Fragebogen und eine persönliche Befragung Gesundheitszustand und relevante Vorerkrankungen zu ermitteln, die zur Identifizierung und zum Ausschluss von Personen beitragen können, deren Spende mit einem Gesundheitsrisiko für sie selbst oder mit dem Risiko einer Krankheitsübertragung für andere verbunden sein könnte. Zudem muss die Anamnese Fragen abdecken, die die Spenderauswahlkriterien (Ausschlusskriterien) der Hämotherapie-Richtlinie abbilden, da diese die rechtlich verbindliche Entscheidungsgrundlage für die Spenderauswahl darstellen. Es steht dafür ein 2015 aktualisierter standardisierter Fragebogen zur Verfügung (www.pei.de/ spenderfragebogen), dessen Anwendung durch das Votum 41 des Arbeitskreises Blut [151] empfohlen wird. Für Rückfragen und Erklärungen muss ein Arzt zur Verfügung stehen.

Perinatal HIV-infizierte Kinder, die seit Geburt effektiv über Jahre antiretroviral behandelt werden und theoretisch potentielle Blutspender werden könnten, können aufgrund der frühen HIV-Suppression HIV-Antikörper negativ sein, haben keine messbare viral load im Plasma, aber HIV-DNA in ihren Blutzellen [152]. Durch Angabe der HIV-Infektion und/oder das Offenlegen der regelmäßigen Einnahme von antiretroviralen Medi- kamenten werden sie von der Spende ausgeschlossen.

\subsection{Spenderinformation und -beratung}

Das Verfahren zur Information des Spenders bei positivem HIV-Befund ist im Look back-Verfahren des AK Blut geregelt [117]. Der HIV-infizierte Spender soll vom Blutspendedienst mündlich und schriftlich darüber aufgeklärt werden, dass er auf Lebenszeit in Deutschland als Blut-, Plasma- und Organspender ungeeignet ist. Bei der Nierentransplantation auf HIVinfizierte Empfänger in Südafrika deuten sich Ausnahmen an [153].

HIV-infizierte Spender/innen werden beraten und an den Hausarzt oder ein spezialisiertes Zentrum zur weiteren Betreuung überwiesen. Die Beratung sollte Informationen über die Übertragungswege von HIV und die Möglichkeit einer antiretroviralen Therapie beinhalten [116, 154] - siehe auch 3.4.

Die Abklärung der möglichen Infektionsquelle des Spenders liegt im allgemeinen infektionsepidemiologischen Interesse. Es sollte im Gespräch mit dem Spender versucht werden, Infektionsweg und Infektionsquelle zu identifizieren, vor allem um weitere HIV-Infektionen zu verhindern. Zudem ist die Angabe für die anonyme Meldepflicht nach Transfusions- und Infektionsschutzgesetz erforderlich. Eine Vorlage des RKI mit standardisierten Fragen vereinfacht die Abklärung und unterstützt eine bundesweit einheitliche Erfassung der HIV-Übertragungswege bei Spendern.

\section{Empfänger}

\subsection{Prävalenz und Inzidenz von blutassoziierten HIV-Infektionen und Infektionskrankheiten bei Empfängerkollektiven}

Bis zur Einführung der obligatorischen Testung auf HIV-Antikörper im Mai bzw. Oktober 1985 wurden durch Blutspenden und einige Blutprodukte etwa 1.380 Hämophile und etwa 200 Transfusionsempfänger in Deutschland mit HIV infiziert [155]. Mit der Einführung von Antikör- 
Tab. 3 Übersicht der zur HIV-Therapie verfügbaren Substanzen - siehe auch Deutsch-Österreichische Leitlinie Antiretrovirale Therapie - www.dgi-net/de/Leitlinie/055-001) und [171]

\begin{tabular}{|lllll}
\hline $\begin{array}{l}\text { Nukleosid/Nukleotid } \\
\text { Reverse Transkriptase- } \\
\text { Inhibitoren (NRTI) }\end{array}$ & $\begin{array}{l}\text { Nicht Nukleosid Re- } \\
\text { verse Transkriptase } \\
\text { Inhibitoren (NNRTI) }\end{array}$ & $\begin{array}{l}\text { Protease In- } \\
\text { hibitoren (PRI } \\
\text { oder PI) }\end{array}$ & $\begin{array}{l}\text { Integrase } \\
\text { Inhibitoren } \\
\text { (INI) }\end{array}$ & $\begin{array}{l}\text { Entry Inhi- } \\
\text { bitoren }\end{array}$ \\
\hline $\begin{array}{l}\text { Azidothymidin -Zido- } \\
\text { vudin (1987) }\end{array}$ & Nevirapin (1996) & Saquinavir (1995) & $\begin{array}{l}\text { Raltegravir } \\
\text { (2007) }\end{array}$ & $\begin{array}{l}\text { Enfuvirtide } \\
\text { (T20) (2003) }\end{array}$ \\
\hline Didanosin (1991) & Efavirenz (1998) & Indinavir (1996) & $\begin{array}{l}\text { Elvitegravir } \\
\text { (2013) }\end{array}$ & $\begin{array}{l}\text { Maraviroc } \\
\text { (2007) }\end{array}$ \\
\hline Zalcitabin (1992) & Delavirdin ${ }^{\text {b (2007) }}$ & Ritonavir (1996) & $\begin{array}{l}\text { Dolutegravir } \\
\text { (2013) }\end{array}$ & \\
\hline Stavudin (1994) & Etravirin (2008) & Nelfinavir (1997) & \\
\hline Lamivudin (1995) & Rilpivirin (2011) & $\begin{array}{l}\text { Lopinavir + Ri- } \\
\text { tonavir (2000) }\end{array}$ & \\
\hline Abacavir (1998) & Atazanavir (2003) & \\
\hline Tenofovir (2001) & Fosamprenavir & \\
\hline Emtricitabin (2003) & Tripanavir (2005) & \\
\hline & Darunavir (2006) & \\
\hline ZZulassungsjahr in Klammern. & & \\
bIn Deutschland nicht zugelassen. & & & \\
\hline
\end{tabular}

persuchtesten und der obligatorischen $\mathrm{Vi}$ rusinaktivierungsverfahren für HIV und Hepatitisviren bei der Herstellung von Plasmaderivaten sank die Anzahl solcher Übertragungen bis 1987 erheblich. Durch die Testung auf HIV-Antikörper und HIV-RNA seit 2004 reduzierte sich die mögliche Belastung des Ausgangsmaterials weiter [146]. Durch Plasmaderivate ist seit 1990/91 keine HIV-Infektion mehr übertragen worden [131, 156].

Nach den Meldungen an das PaulEhrlich-Institut fanden seit der Einführung des NAT-Screenings im Jahr 2004 zwei HIV-Übertragungen durch zelluläre Blutkomponenten (Erythrozytenkonzentrate) statt [157]. Beide Übertragungen waren die Folge eines Testversagens der verwendeten NAT-Systeme. Bei einem Übertragungsfall im Jahr 2007 führten wahrscheinlich eine geringe Viruslast und Virusmutationen in der Primerbindungsregion zum falsch negativen Testergebnis [158]. Bei der 2009 registrierten Übertragung wurde die HIV-positive Spenderprobe mit dem verwendeten NAT-System wiederholt negativ getestet [131].

Das Risiko einer transfusionsbedingten HIV-Übertragung wird als sehr gering eingeschätzt. Basierend auf den Daten zur Spendertestung und zur Hämovigilanz im Zeitraum 2007-2010 wird ein Übertragungsrisiko von $1 \mathrm{zu}$ 9,64 Millionen Spenden angegeben [132]. Nimmt man neuere
Restrisikomodelle, die konkrete Spenderintervalle in die Schätzung einbeziehen, liegt das geschätzte Restrisiko einer unerkannt infektiösen Vollblutspende etwas höher bei $1 \mathrm{zu}$ 2,4 Millionen [159].

Wie bei HIV-infizierten Spendern sind auch bei HIV-infizierten Empfängern Lymphozyten und Plasma zu asservieren [117], um wenn möglich die Infektionsquelle und die Übertragung mit molekularen Methoden abzuklären (siehe 2.3).

\subsection{Abwehrlage (Resistenz, vorhandene Immunität, Immunreaktivität, Alter, exogene Faktoren)}

Eine protektive Immunität gegen HIV gibt es nicht. Bei bestehender Infektion mit HIV-1 M:B kann der Infizierte mit einem anderen HIV-1-M:B-Stamm jederzeit überinfiziert werden [77]. Eine HIV2-Infektion schützt nicht vor einer Infektion mit HIV-1 und umgekehrt [160]. Inwieweit Mutationen $(\Delta 32$-Deletion, $\mathrm{Mu}-$ tationen) im CCR5-Gen eine parenterale Infektion behindern, bleibt weiterhin fraglich [61, 161]. In Deutschland trägt etwa $1 \%$ der Bevölkerung diese Mutation, somit ist sie infektionsepidemiologisch irrelevant. Epidemiologische Untersuchungen weisen darauf hin, dass für eine sexuelle HIV-Übertragung auf eine Person, die homozygot für die $\Delta 32$-Deletion im CCR5-Gen ist, eine höhere HIV-Dosis notwendig sein kann. Innerhalb der ersten Jahre kann der Krankheitsverlauf bei Personen, die heterozygot für die $\Delta 3$ 2-Mutationen sind, verlangsamt sein [62]. Personen mit der CCR5- $\Delta 32$-Deletion haben jedoch eine hohe Wahrscheinlichkeit, z.B. eine West-Nil-Virus-Enzephalitis zu entwickeln $[162,163]$. Je älter ein Patient zum Zeitpunkt der Infektion ist, desto höher ist das Risiko, frühzeitig eine Immunschwäche zu entwickeln [164-166].

HIV-Impfung: Seit 1983 wird mit hohem personellen und finanziellen Aufwand versucht, einen Impfstoff gegen HIV zu entwickeln. Bisher waren alle Versuche weiterführend, aber erfolglos, und bis zur Herstellung eines wirksamen präventiven Impfstoffs werden noch Jahre vergehen $[167,168]$.

\subsection{Schweregrad und Verlauf der Erkrankung}

Die Infektion mit HIV verläuft immer chronisch und endet ohne antiretrovirale Therapie tödlich. CD4-Zellzerstörung und klinische Symptomatik können über eine antiretrovirale Therapie verzögert bzw. für Jahrzehnte unterdrückt werden [169]. Bei unbehandelten HIV-1-Infektionen treten im Mittel AIDS-definierende Symptome nach etwa 10 Jahren, mit einem Bereich von 2 bis 25 Jahren, auf. Durch HIV-2 induziertes AIDS wird mit einem Mittel von 15 Jahren manifest (siehe 1.2). Durch die antiretrovirale Therapie gelingt es, die symptomfreie oder -arme Phase über viele Jahre zu verlängern $[170,171]$.

\subsection{Therapiemöglichkeiten}

Seit 1987 und besonders 1996 mit Einführen der Protease-Inhibitoren und 2007 der Integrase-Inhibitoren ist ein erheblicher Fortschritt in der Therapie der HIVInfektion erreicht worden. Eingesetzt werden dazu Medikamente mit unterschiedlichem Wirkungsspektrum (nukleosidische [NRTI], nukleotidische [NtRTI] und nicht nukleosidische [NNRTI] reverse Transkriptasehemmer, kombiniert mit Proteasehemmern [PI bzw.PRI]) und/oder zusätzlich ein Fusionsinhibitor [172] oder Integraseinhibitor [INI]. Weitere Medi- 
kamente werden entwickelt [173]. Verfügbare Substanzen sind in $\bullet$ Tab. $\mathbf{3}$ zusammengefasst. Entsprechend der S2-Leitlinien sollte die Initialtherapie der HIVInfektion mit einer sehr wirksamen und zugleich sicheren und gut verträglichen Kombination aus zwei NRTI mit einem NNRTI erfolgen [171]. Eine Kombination von Wirkstoffgruppen soll die Resistenzentwicklung von HIV im Patienten so lange wie möglich hinauszögern. In Deutschland sind bereits bei rund $10-12 \%$ der Patienten vor Beginn der ersten Therapie resistente HIV-Varianten zu erwarten. Dabei ist die Resistenzrate bisher weitgehend stabil [174]. Vor Behandlungsbeginn sollte daher ein genotypischer Resistenztest erfolgen, da ohne die Berücksichtigung von Primärresistenzen die Effektivität der Therapie reduziert ist $[174,175]$.

Die Indikationsstellung zur Therapie sollte im Dialog zwischen spezialisiertem Arzt und informiertem Patienten gestellt werden. Die besten therapeutischen Langzeitresultate sind zu erreichen, wenn mit der Therapie begonnen wird, bevor Zeichen einer Immunschwäche ausgeprägt sind. Entsprechend der Leitlinien sollte eine Therapie erfolgen, wenn die CD4+ -Zellzahl bei oder unter 500/ $\mu$ liegt [165, 176]. In Einzelfällen, besonders bei Neugeborenen, ist es indiziert, früh nach Infektionseintritt, $d$. h. bereits vor oder zu Beginn der Serokonversion, mit der Therapie zu beginnen. Auch bei einer Frühtherapie ist zu prüfen, ob medikamentenresistente Viren übertragen wurden [177179].

Nur ein Teil der Medikamente ist gegen HIV-2 wirksam [180]. Nach Einnahme und Wirkung der Antiretroviralia kann sich die Funktion des Immunsystems erholen und folglich die klinische Symptomatik verschwinden bzw. verbessern. Eine Elimination des HIV aus dem Körper des Infizierten durch Therapie ist bisher nicht möglich - einzige Ausnahme ist der „Berlin Patient" nach Knochenmarktransplantation von einem Spender mit homozygoter CCR5- $\Delta 32$-Deletion [181].

Nebenwirkungen: Auch wenn eine Kombination von drei oder vier Medikamenten teils sehr gut die HIV-Replikation unterdrückt, ist die Einnahme mit Nebenwirkungen verbunden, die die Lebensqualität erheblich einschränken können.
Ferner interferieren antiretrovirale Medikamente teils miteinander und mit anderen Medikamenten über das Cytochrom p450-System, so dass Spezialkenntnisse für die Verordnung erforderlich sind [182]. Typische sichtbare Veränderungen, ausgelöst durch Therapie mit PI/PRI, am Körper sind Lipodystrophie, vor allem Abbau des Bichat'schen Fettpfropfes und des subkutanen Fettes der Extremitäten, Einlagerung von umbilikalem und nuchalem Fett. Häufige Nebenwirkungen sind Diarrhoen, Schlafstörungen, Konzentrationsschwächen und mangelnde Gewichtszunahme trotz ausreichender Nahrungszufuhr, ferner Diabetes, Anämie und neurologische Affektionen [5, 29].

Eine optimale Therapie ist gegenwärtig bei Infektion mit HIV-1B und anderen Viren der Gruppe M möglich. Zu berücksichtigen ist, dass einzelne HIV-1 Gruppe M-Subtypen, HIV-1 Gruppe O und HIV-2 bereits natürliche Resistenzen gegen NNRTI und PRI aufweisen [175, 180].

Eine adjuvante Immuntherapie durch Interleukine, z. B. Interleukin 2, oder potentiell präventive Vakzine oder therapeutische Vakzine, hat bisher nicht zu einem sichtbaren und dauerhaften Erfolg der Stützung von Immunfunktion und Verminderung der HIV-Vermehrung geführt [168, 183-186].

\subsection{HIV-Übertragbarkeit}

HIV wird übertragen durch Körperflüssigkeiten wie Blut, Plasma bzw. Serum, Genitalsekrete und transplantierte Organe wie Niere, Knochen, Cornea u. a.; Übertragungen über künstliche Insemination sind vorgekommen. Übertragungen über Speichel und Bissverletzungen wurden in Einzelfällen berichtet; ein Fall aus jüngerer Zeit wurde aus China berichtet [187]. Offene Wunden können eine Eintrittspforte für HIV sein [188]. Eine HIV-Übertragung über Nadelstichverletzung ist möglich, da bei hohem Virustiter und möglicher Übertragung HIV-haltiger Zellen sehr kleine Mengen Blut ausreichen $[189,190]$. HIV wird weder über Aerosole noch soziale Kontakte, Stiche von Insekten oder Arthropoden, noch über Nahrungsmittel oder Wasser übertragen.

\subsection{Häufigkeit der Applikation sowie Art und Menge der Blutprodukte}

Blutkomponenten: Seit 2004 wurden in Deutschland nur zwei HIV-Übertragungen durch Blutkomponenten gemeldet [157]. Wenn eine human-infektiöse Dosis (1 HID entspricht etwa 500 bis 1.000 HIV-Partikeln) in der applizierten Menge der Blutkomponente vorhanden ist, wird HIV übertragen [190]. Es gibt den Hinweis, dass nach Stichverletzung bei sofortigem Therapiebeginn eine HIV-Infektion im Einzelfall verhindert werden kann [189, 191, 192].

Plasmaderivate: Von den Plasmaderivaten haben im Wesentlichen FaktorVIII- und -IX- sowie PPSB-Präparate im Zeitraum von 1979 bis 1989 zu HIV-Übertragungen geführt. Albumin, Antithrombin III (AT-III) und i.m. oder i.v. Immunglobulin-Präparate haben HIV auch vor Einführung spezieller Verfahrensschritte zur Abreicherung und Inaktivierung von Viren nicht übertragen. Durch die eingeführte Spenderselektion, Testung und Inaktivierung ist eine Übertragung von umhüllten Viren, die ähnlich wie HIV aufgebaut sind, nicht mehr gegeben.

\section{4. Blutprodukte}

\subsection{Belastung des Ausgangsmaterials und Testmethoden}

Bedingt durch Spenderselektion, Testung der Spenden auf HIV-Antikörper und HIV-1-Genom (NAT) ist die Belastung von Blut und entsprechend Blutprodukten mit unter $1 \mathrm{zu} 1$ Million sehr gering (siehe 2.1 und 2.3). Zusätzlich wird Plasma zur Fraktionierung, das durch Plasmapherese gewonnen wird, häufig für mindestens 60 Tage für die Verarbeitung gesperrt, so dass es möglich ist, Spenden, die von Spendern in der Serokonversionsphase stammen, aufgrund einer Nachtestung (Post-Donation-Information) im Rahmen des Look back-Prozesses zu eliminieren. Durch diese Maßnahme wird die theoretische Virusbelastung von Plasmapools zur Herstellung von Plasmaderivaten weiter reduziert. 


\subsection{Möglichkeiten zur Abtrennung und Inaktivierung von Infektionserregern}

Die Herstellung und Reinigung von Einzelproteinen aus Plasma ist nicht ausreichend um HIV vollkommen zu entfernen, und es müssen validierte Verfahren zur effektiven Abreicherung und Inaktivierung von Viren eingesetzt werden [193]. Seit der konsequenten Anwendung effektiver Inaktivierungsverfahren bei der Herstellung von Plasmaderivaten und/oder Entfernung von Viren sind keine HIV-Übertragungen durch Plasmaderivate mehr berichtet worden. Folglich ist die experimentell ermittelte Inaktivierungskapazität der Herstellungsverfahren auch epidemiologisch belegt.

HIV ist labil gegenüber Hitze und Detergentien (siehe 1.1). Es lässt sich durch das Solvent/Detergenz (SD)-Verfahren, z. B. mit Reagenzien wie Tri-N-Butyl-Phosphat (TNBP) und Triton X100 bzw. Polysorbat 80 inaktivieren [194196]. Durch Pasteurisierung bei $60^{\circ} \mathrm{C}$ für 10 Stunden selbst in Gegenwart von Stabilisatoren wird HIV zuverlässig inaktiviert [197]. Hitzeeinwirkung auf das lyophilisierte Produkt bei z. B. $80^{\circ} \mathrm{C}$ für 72 Stunden oder $100^{\circ} \mathrm{C}$ für (mindestens) $30 \mathrm{Mi}$ nuten und entsprechender Restfeuchtigkeit von etwa $1 \%$ führt zur HIV-Inaktivierung [198-200].

Da Plasmaproteine ebenfalls labil gegenüber Hitzeeinwirkung sind, müssen die Inaktivierungsschritte unter geeigneten, validierten Bedingungen durchgeführt werden [201]. Das Produkt sollte optimal in seiner biologischen Aktivität und natürlichen Konformation erhalten bleiben, und gleichzeitig sollten mögliche kontaminierende Viren inaktiviert werden [202, 203]. Behandlung mit $\beta$-Propiolacton und UV-Licht [53] ist bei niedriger Proteinkonzentration angewendet wirksam, jedoch nicht in Plasma. Eine HIV-Übertragung wurde durch $\beta$-Propiolacton-Behandlung eines PPSP-Präparates nicht verhindert [204].

Weitere Verfahren zur Inaktivierung von HIV und anderen Viren in Blutkomponenten sind entwickelt worden. Dies sind chemische, z. B. Inactine, photodynamische, z. B. Methylenblau, Riboflavin und photochemische Verfahren, z. B.
Psoralen S-58 [205-211]. Klinische Studien zur Wirksamkeit und Verträglichkeit von Methylenblau- und SD-inaktiviertem und von Amotosalen- [208] und Riboflavin-behandeltem Plasma [211] sind nur begrenzt durchgeführt worden [212]. Eine weitere Substanz zur Inaktivierung von HIV in Vollblut oder Erythrozytenkonzentrat ist S-303 [213]. Generell sollte bei Viren wie HIV eine infektiöse Dosis von $6 \log _{10}\left(10^{6}\right)$ pro ml inaktiviert werden können [214]; eine Kapazität, die von einigen der oben zitierten Verfahren nicht erreicht wird.

\subsection{Praktikabilität und Validierbarkeit der Verfahren zur Elimination/ Inaktivierung von HIV}

Die Validierung der verschiedenen Eliminierungs- und Inaktivierungsschritte muss unter Herstellungsbedingungen und Verwendung von HIV durchgeführt werden [193, 215, 216]. HIV ist in ausreichender Menge in Kulturzellen anzüchtbar, so dass das Ausgangsmaterial der Einzelschritte der Produktherstellung im Labor mit HIV versetzt werden kann, der Einzelschritt entsprechend den Produktionsbedingungen durchgeführt und so die HIV-Abreicherung, bzw. Eliminierung oder Inaktivierung pro Verfahrensschritt gemessen werden kann. Da HIV-1 und HIV-2 im Inaktivierungsverhalten als identisch gelten, ist die Verwendung von HIV-1 für die Validierung eines Verfahrens ausreichend. Auch wenn sich HIV-1 und SIVmac239 (simian immunodeficiency virus - siehe - Abb. 2) bei der Inaktivierung etwa gleich verhalten [217], ist die Verwendung von SIV nicht akzeptiert.

\section{Bewertung}

Das Auftreten von HIV in Spenderkollektiven für Blut und Plasma seit 1979 hat dazu geführt, dass die Virussicherheitsstandards für die Herstellung von Blutkomponenten und Plasmaderivaten zunehmend verbessert wurden.

Seit der Einführung der HIV-Antikörpertestung in Blut- und Plasmaspenden im Jahr 1985 und der HIV-NAT im Jahr 2004 sind Infektionen über Blut und Blutkomponenten sehr selten geworden.
Durch Einführen der NAT aufHIV-1-Genom wird das durch die Antikörperbildung bedingte diagnostische Fenster von etwa 21 bis 45 Tagen auf etwa 11 Tage reduziert. Das Restrisiko der HIV-Übertragung durch Erythrozyten-, Granulozyten- und Thrombozytenkonzentrate, die keinem Virusinaktivierungs-/Eliminierungsverfahren unterzogen werden, ist niedrig und beträgt abhängig von der Risikomodellierung etwa 1 in 1 Million bis 1 in 10 Millionen Spenden. Durch Verwenden von gefrorenem Frischplasma (GFP/ FFP), das der Quarantänelagerung unterliegt, ist seit 1994 keine HIV-Übertragung mehr bekannt geworden.

Um die Virussicherheit von Plasmaderivaten bewerten zu können, wurde vorgeschrieben, die Kapazität des Herstellungsverfahrens, Viren zu inaktivieren und/oder zu entfernen, zu validieren. Nur Produkte mit einer hohen Sicherheitsmarge für HIV (und Hepatitisviren) werden von den Behörden zugelassen. Die Validierung gibt auch einen Hinweis auf die Virussicherheit dieser Produkte im Hinblick auf bisher unbekannte, neu auftretende umhüllte Viren.

Nachdem die Spendertestung eingeführt wurde und validierte Verfahren zur Herstellung von Plasmaderivaten eingesetzt werden müssen, sind seit 1990/1991 keine HIV-Übertragungen über Plasmaderivate beobachtet worden; zur Zeit besteht kein messbares Restrisiko einer HIV-Übertragung durch Plasmaderivate.

Nachdem HIV-Stämme zirkulieren, die über Mutation in oder Deletion von Primerbindungsregionen in der NAT nicht erkannt wurden, wurde zur Erhöhung der Sicherheit die dual target-NAT vorgeschrieben. HIV bleibt aber genetisch variabel, und um den erreichten Sicherheitsstandard zu erhalten, besteht weiterhin Forschungsbedarf, auch um auftretende HIV-Varianten durch kontinuierliches Monitoring erkennen und Nachweisteste frühzeitig anpassen zu können.

Dieses Papier wurde fertiggestellt am 16.01.2015 und vom Arbeitskreis Blut am 29.05.2015 verabschiedet. Es ersetzt die gleichlautende Stellungnahme des AK Blut vom 02.10.2003. Es wurde erarbeitet von den Mitgliedern der Untergruppe „Bewertung Blut-assoziierter Krankheitserreger“ des Arbeitskreises Blut: Prof. Dr. 
Lutz Gürtler, Prof. Dr. Martin Aepfelbacher, Dr. Ursula Bauerfeind, PD Dr. Johannes Blümel, Prof. Dr. Reinhard Burger, Prof. Dr. Barbara Gärtner, Dr. Albrecht Gröner, Dr. Margarethe Heiden, Prof. Dr. Martin Hildebrandt, Prof. Dr. Dr. Bernd Jansen, Dr. Ruth Offergeld, Prof. Dr. Georg Pauli, Dr. Uwe Schlenkrich, Dr. Volkmar Schottstedt, Prof. Dr. Rainer Seitz, Dr. Johanna Strobel, Dr. Hannelore Willkommen.

\section{Literatur}

1. Luciw PA (1996) Human immunodeficiency viruses and their replication. In: Fields BN (Hrsg) Virology, 3. Aufl. Lippincott-Raven, Philadelphia, S 1881-1952

2. Gao F, Bailes E, Robertson DL et al (1999) Origin of HIV-1 in the chimpanzee Pan troglodytes troglodytes. Nature 397:436-441

3. Sharp PM, Hahn BH (2011) Origins of HIV and the AIDS pandemic. Cold Spring Harb Perspect Med 1:a006841

4. Faria NR, Rambant A, Suchard MA et al (2014) HIV epidemiology. The early spread and epidemic ignition of HIV-1 in human populations. Science 346:56-61

5. Levy JA (2007) HIV and the Pathogenesis of AIDS, 3. Aufl. ASM Press, Washington

6. Sauter D, Unterweger D, Vogl M et al (2012) Human tetherin exerts strong selection pressure on the HIV-1 group N Vpu protein. PLoS Pathog 8:e1003093

7. Vincenzi E, Poli G (2013) Novel factors interfering with human immunodeficiency virus-type 1 replication in vivo and in vitro. Tissue Antigens 81:61-71

8. Kuiken C, Leitner T, Hahn B et al (2012) HIV Sequence Compendium 2012. Los Alamos National Lab, Los Alamos. http://www.hiv.lanl.gov. Zugegriffen: 24. Sept. 2015

9. Simon F, Mauclère $P$, Roques $P$ et al (1998) Identification of a new human immunodeficiency virus type 1 distinct from group $\mathrm{M}$ and group 0 . Nat Med 4:1032-1037

10. Plantier JC, Leoz M, Dickerson JE et al (2009) A new human immunodeficiency virus derived from gorillas. Nat Med 15:871-872

11. Vallari A, Holzmayer V, Harris B et al (2011) Confirmation of putative HIV-1 group P in Cameroon. J Virol 85:1403-1407

12. Peeters M, Sharp PM (2000) Genetic diversity of HIV-1: the moving target. AIDS 14(suppl 3):S129S140

13. Ward MJ, Lycett SJ, Kalish ML, Rambaut A, Leigh Brown AJ (2013) Estimating the rate of intersubtype recombination in early HIV-1 group M strains. J Virol 87:1967-1973

14. Chow WZ, Al-Darraji H, Lee YM, Takebe Y, Kamarulzaman A, Tee KK (2012) Genome sequences of a novel HIV-1 CRF53_01B identified in Malaysia. J Virol 86:11398-11399

15. Jia L, Li L, Li H et al (2014) Recombination pattern reanalysis of some HIV-1 circulating recombination forms suggest the necessity and difficulty of revision. PLoS One 9:e107349
16. Pessôa R, Watanabe JT, Calabria P et al (2014) Deep sequencing of HIV-1 near full-length proviral genomes identifies high rates of BF1 recombinants including two novel circulating recombinant forms (CRF)70_BF1 and a disseminating 71 BF1 among blood donors in Pernambuco, Brazil. PLoS One 9:e112674

17. McCutchan FE (2000) Understanding the genetic diversity of HIV-1. AIDS 14(suppl 3):S31-S44

18. Takehisa J, Zekeng L, Ido E et al (1999) Human immunodeficiency virus type 1 intergroup (M/O) recombination in Cameroon. J Virol 73:68106820

19. Gürtler LG, Hauser PH, Eberle J et al (1994) A new subtype of human immunodeficiency virus type 1 (MVP-5180) from Cameroon. J Virol 68:15811585

20. Vanden Haesevelde M, Decourt JL, De Leys RJ et al (1994) Genomic cloning and complete sequence analysis of a highly divergent African human immunodeficiency virus isolate. J Virol 68:1586-1596

21. Roques $P$, Robertson $D L$, Souquière $S$ et al (2002) Phylogenetic analysis of 49 newly derived HIV-1 group 0 strains: high viral diversity but no group M-like subtype structure. Virology 302:259-273

22. Brennan CA, Yamaguchi J, Devare SG, Foster GA, Stramer SL (2010) Expanded evaluation of blood donors in the United States for human immunodeficiency virus type 1 non-B subtypes and antiretroviral drug-resistant strains: 2005 through 2007. Transfusion 50:2707-2712

23. Mourez T, Simon F, Plantier JC (2013) Non-M variants of human immunodeficiency virus type 1. Clin Microbiol Rev 26:448-461

24. Gelderblom HR (1991) Assembly and morphology of HIV: potential effect of structure on viral function. AIDS 5:617-637

25. Parren PW, Moore JP, Burton DR, Sattentau QJ (1999) The neutralizing antibody response to HIV-1: viral evasion and escape from humoral immunity. AIDS 13(suppl A):S137-S162

26. Niedrig M, Gelderblom HR, Pauli G et al (1994) Inhibition of infectious human immunodeficiency virus type 1 particle formation by Gag proteinderived peptides. J Gen Virol 75:1469-1474

27. Gelderblom HR, Reupke H, Pauli G (1985) Loss of envelope antigens of HTLV-III/LAV, a factor in AIDS pathogenesis? Lancet 2 (8462):1016-1017

28. Selhorst $\mathrm{P}$, Grupping K, Tong T et al (2013) M48U1 CD4 mimetic has a sustained inhibitory effect on cell-associated HIV-1 by attenuating virion infectivity through gp120 shedding. Retrovirology 10:12

29. Levy JA (2011) Virus-host interactions in HIV pathogenesis: directions for therapy. Adv Dent Res 23:13-18

30. Leonard J, Parrott C, Buckler-White AJ, Turner W, Ross EK, Martin MA, Rabson AB et al (1989) The NF-kappa $B$ binding sites in the human immunodeficiency virus type 1 long terminal repeat are not required for virus infectivity. J Virol 63:4919_ 4924

31. Quiñones-Mateu ME, Mas A, Lain de Lera T et al (1998) LTR and tat variability of HIV-1 isolates from patients with divergent rates of disease progression. Virus Res 57:11-20

32. Santiago ML, Range F, Keele BF et al (2005) Simian immunodeficiency virus infection in free-ranging sooty mangabeys (Cercocebus atys atys) from the Taï Forest, Côte d'Ivoire: implications for the origin of epidemic human immunodeficiency virus type 2. J Virol 79:12515-12527
33. Locatelli S, Peeters M (2012) Cross-species transmission of simian retroviruses: how and why they could lead to the emergence of new diseases in the human population. AIDS 26:659-673

34. Courgnaud V, Salemi M, Pourrut X et al (2002) Characterization of a novel simian immunodeficiency virus with a vpu gene from greater spotnosed monkeys (Cercopithecus nictitans) provides new insights into simian/human immunodeficiency virus phylogeny. J Virol 76:8298-8309

35. Courgnaud V, Pourrut X, Bibollet-Ruche F et al (2001) Characterization of a novel simian immunodeficiency virus from guereza colobus monkeys (Colobus guereza) in Cameroon: a new lineage in the nonhuman primate lentivirus family. JVirol 75:857-866

36. Damond F, Apetrei C, Robertson DL et al (2001) Variability of human immunodeficiency virus type 2 (HIV-2) infecting patients living in France. Virology 280:19-30

37. Brun-Vézinet $F$, Charpentier C (2013) Update on the human immunodeficiency virus. Med Mal Infect 43:177-184

38. Chang M, Gottlieb GS, Dragavon JA et al (2012) Validation for clinical use of a novel HIV-2 plasma RNA viral load assay using the Abbott $\mathrm{m} 2000$ platform. J Clin Virol 55:128-133

39. Dean M, Carrington M, Winkler C et al (1996) Genetic restriction of HIV-1 infection and progression to AIDS by a deletion allele of the CKR5 structural gene. Science 273:1856-1862

40. Feng Y, Broder CC, Kennedy PE, Berger EA (1996) HIV-1 entry cofactor: functional CDNA cloning of a seven-transmembrane, $\mathrm{G}$ protein-coupled receptor. Science 272:872-877

41. Archin NM, Sung JM, Garrido C, Soriano-Sarabia N, Margolis DM (2014) Eradicating HIV infection: seeking to clear a persistent pathogen. Nat Rev Microbiol 12:750-764

42. Stein BS, Gowda SD, Lifson JD, Penhallow RC, Bensch KG, Engleman EG (1987) pH-independent HIV entry into CD4-positive T cells via virus envelope fusion to the plasma membrane. Cell 49:659-668

43. Sousa R, Chung YJ, Rose JP, Wang BC (1993) Crystal structure of bacteriophage T7 RNA polymerase at 3.3 A resolution. Nature 364:593-599

44. Pan X, Baldauf HM, Keppler OT, Fackler OT (2013) Restrictions to HIV-1 replication in resting CD4 + T lymphocytes. Cell Res 23:876-885

45. Moudgil T, Daar ES (1993) Infectious decay of human immunodeficiency virus type 1 in plasma. J Infect Dis 167:210-212

46. Perelson AS, Neumann AU, Markowitz M, Leonard JM, Ho DD (1996) HIV-1 dynamics in vivo: virion clearance rate, infected cell life-span, and viral generation time. Science 271:1582-1586

47. Zeng M, Southern PJ, Reilly CS et al (2012) Lymphoid tissue damage in HIV-1 infection depletes naïve T cells and limits T cell reconstitution after antiretroviral therapy. PLoS Pathog 8:e1002437

48. Herbein G, Van Lint C, Lovett JL, Verdin E (1998) Distinct mechanisms trigger apoptosis in human immunodeficiency virus type 1-infected and in uninfected bystander T lymphocytes. J Virol 72:660-670

49. Zhang YJ, Fadeel B, Hodara V, Fenyö EM (1997) Induction of apoptosis by primary HIV-1 isolates correlates with productive infection in peripheral blood mononuclear cells. AIDS 11:1219-1225

50. Martin LS, McDougal JS, Loskoski SL (1985) Disinfection and inactivation of the human T lymphotropic virus type III/lymphadenopathy-associated virus. J Infect Dis 152:400-403 
51. McDougal JS, Martin LS, Cort SP, Mozen M, Heldebrant CM, Evatt BL (1985) Thermal inactivation of the acquired immunodeficiency syndrome virus, human T-lymphotropic virus-III/lymphadenopathy-associated virus, with special reference to antihemophilic factor. J Clin Invest 76:875-877

52. Pruss $A$, Kao $M$, Kiesewetter $H$, von Versen $R$, Pauli G (1999) Virus safety of avital bone tissue transplants: evaluation of sterilization steps of spongiosa cuboids using a peracetic acid-methanol mixture. Biologicals 27:195-201

53. Spire B, Dormont D, Barré-Sinoussi F, Montagnier L, Chermann JC (1985) Inactivation of lymphadenopathy-associated virus by heat, gamma rays, and ultraviolet light. Lancet 1(8422):188-189

54. Pruss A, Kao M, Gohs U, Koscielny J, von Versen $R$, Pauli G (2002) Effect of gamma irradiation on human cortical bone transplants contaminated with enveloped and non-enveloped viruses. Biologicals 30:125-133

55. Mohr H, Steil L, Gravemann U et al (2009) A novel approach to pathogen reduction in platelet concentrates using short-wave ultraviolet light. Transfusion 49:2612-2624

56. Kim IS, Choi YW, Kang Y, Sung HM, Shin JS (2008) Dry-heat treatment process for enhancing viral safety of an antihemophilic factor VIII concentrate prepared from human plasma. J Microbiol Biotechnol 18:997-1003

57. Bonner K, Siemieniuk RA, Boozary A, Roberts T, Fajardo E, Cohn J (2014) Expanding access to HIV viral load testing: a systematic review of RNA stability in EDTA tubes and PPT beyond current time and temperature thresholds. PLoS One 9:e113813

58. Zanetti AR, Bodini U, Clerici M et al (2007) Transfusion of red blood cells from an HIV-RNA-positive/anti-HIV-negative donor without HIV infection in the recipient. Transfusion 47:1328-1329

59. Demirkhanyan L, Marin M, Lu W, Melikyan GB (2013) Sub-inhibitory concentrations of human a-defensin potentiate neutralizing antibodies against HIV-1 gp41 pre-hairpin intermediates in the presence of serum. PLoS Pathog 9:e1003431.

60. Pauls $E$, Jiminez $E$, Ruiz A et al (2013) Restriction of HIV-1 replication in primary macrophages by IL-12 and IL-19 through the upregulation of SAMHD1. J Immunol 190:4736-4741

61. Meng G, Wei X, Wu X et al (2002) Primary intestinal epithelial cells selectively transfer R5 HIV-1 to CCR5 + cells. Nat Med 8:150-156

62. Arrildt KT, Joseph SB, Swanstrom R (2012) The HIV-1 env protein: a coat of many colors. Curr HIV/AIDS Rep 9:52-63

63. Maher D, Wu X, Schacker T, Horbul J, Southern P (2005) HIV binding, penetration, and primary infection in human cervicovaginal tissue. Proc Natl Acad Sci U S A 102:11504-11509

64. Grivel JC, Elliott J, Lisco A et al (2007) HIV-1 pathogenesis differs in rectosigmoid and tonsillar tissues infected ex vivo with CCR5- and CXCR4tropic HIV-1. AIDS 21:1263-1272

65. Liuzzi G, Chirianni A, Clementi M et al (1996) Analysis of HIV-1 load in blood, semen and saliva: evidence for different viral compartments in a cross-sectional and longitudinal study. AIDS 10:F51-F56

66. Bourlet T, Cazorla C, Berthelot P et al (2001) Compartmentalization of HIV-1 according to antiretroviral therapy: viral loads are correlated in blood and semen but poorly in blood and saliva. AIDS 15:284-285
67. Grosch-Wörner I, Schäfer A, Obladen M et al (2000) An effective and safe protocol involving zidovudine and caesarean section to reduce vertical transmission of HIV-1 infection. AIDS 14:2903-2911

68. Gibb MD, Tess BH (1999) Interventions to reduce mother-to-child transmission of HIV infection: new developments and current controversies. AIDS 13(suppl A):S93-S102

69. Burin des Roziers N, Sotto A, Arnaud A, Saissi G, Nasar O, Jourdan J (1995) Kinetics of detection of antibodies to HIV-1 and plasma p24 antigens during a severe primary HIV-1 infection. AIDS 9:528-529

70. Lindbäck S, Thorstensson R, Karlsson AC et al (2000) Diagnosis of primary HIV-1 infection and duration of follow-up after HIV exposure: karolinska Institute Primary HIV Infection Study Group. AIDS 14:2333-2339

71. Vermeulen M, Coleman C, Mitchel J et al (2013) Comparison of human immunodeficiency virus assays in window phase and elite controller samples: viral load distribution and implications for transmission risk. Transfusion 53:2384-2398

72. Cockerham LR, Hatano H (2015) Elite control of HIV: is this the right model for a functional cure? Trends Microbiol 23:71-75

73. Michael NL, Chang G, Kim JH, Birx DL (1997) Dynamics of cell-free viral burden in HIV-1-infected patients. J Acquir Immune Defic Syndr Hum Retrovirol 14:237-242

74. Schockmel GA, Yerly S, Perrin L (1997) Detection of low HIV-1 RNA levels in plasma. J Acquir Immune Defic Syndr Hum Retrovirol 14:179-183

75. Chun TW, Shawn Justement J, Murray D et al (2013) Effect of antiretroviral therapy on HIV reservoirs in elite controllers. J Infect Dis 208:14431447

76. Kunwar P, Hawkins N, Dinges WL et al (2013) Superior control of HIV-1 replication by $\mathrm{CD} 8+\mathrm{T}$ cells targeting conserved epitopes: implications for HIV vaccine design. PLoS One 8:e64405

77. Altfeld M, Allen TM, Yu XG et al (2002) HIV-1 superinfection despite broad CD8 + T-cell responses containing replication of the primary virus. Nature 420:434-439

78. Kong L, Sattentau QJ (2012) Antigenicity and immunogenicity in HIV-1 antibody-based vaccine design. J AIDS Clin Res S8:3

79. Mocroft A, Johnson MA, Phillips AN (1996) Factors affecting survival in patients with the acquired immunodeficiency syndrome. AIDS 10:10571065

80. Iwuji CC, Churchill D, Gilleece Y, Weiss HA, Fisher M (2013) Older HIV-infected individuals present late and have a higher mortality: Brighton, UK cohort study. BMC Public Health 13:397

81. Ockenga J, Tillmann HL, Trautwein C, Stoll M, Manns MP, Schmidt RE (1997) Hepatitis B and C in HIV-infected patients. Prevalence and prognostic value. J Hepatol 27:18-24

82. Soriano V, Rodríguez-Rosado R, García-Samaniego J (1999) Management of chronic hepatitis $C$ in HIV-infected patients. AIDS 13:539-546

83. Soriano V, Vispo E, Fernandez-Montero JV, Labarga P, Barreiro P (2013) Update on HIV/HCV coinfection. Curr HIV/AIDS Rep 10:226-234

84. Burbelo PD, Kovacs JA, Wagner J et al (2012) The cancer-associated virus landscape in HIV patients with oral hairy leukoplakia, Kaposi's sarcoma, and Non-Hodgkin lymphoma. AIDS Res Treat 2012:634523
85. Brettle RP, Gore SM, Bird AG, McNeil AJ (1993) Clinical and epidemiological implications of the Centers for Disease Control/World Health Organization reclassification of AIDS cases. AIDS 7:531539

86. Tebit DM, Arts EJ (2011) Tracking a century of global expansion and evolution of HIV to drive understanding and to combat disease. Lancet Infect Dis 11:45-56

87. Lemey P, Pybus OG, Wang B, Saksena NK, Salemi $M$, Vandamme AM (2003) Tracing the origin and history of the HIV-2 epidemic. Proc Natl Acad Sci USA 100:6588-6592

88. Robbins KE, Lemey P, Pybus OG et al (2003) U.S. Human immunodeficiency virus type 1 epidemic: date of origin, population history, and characterization of early strains. J Virol 77:6359-6366

89. UNAIDS (2013) Global report: UNAIDS report on the global AIDS epidemic 2013. http://www.unaids.org/en/media/unaids/contentassets/documents/epidemiology/2013/gr2013/UNAIDS Global_Report_2013_en.pdf.Zugegriffen: 24 . Sept. 2015

90. Robert Koch-Institut (2014) Schätzung der Prävalenz und Inzidenz von HIV-Infektionen in Deutschland (Stand: Ende 2013). Epid Bull 44:429-437

91. Robert Koch-Institut (2014) HIV-Infektionen und AIDS-Erkrankungen in Deutschland - Bericht zur Entwicklung im Jahr 2013 aus dem Robert KochInstitut. Epid Bull 26:214-232

92. Robert Koch-Institut (2014) Infektionsepidemiologisches Jahrbuch für 2013. Berlin, Robert KochInstitut

93. Paraskevis D, Pybus O, Magiorkinis G et al (2009) Tracing the HIV-1 subtype B mobility in Europe: a phylogeographic approach. Retrovirology 6:49

94. European Centre for Disease Prevention and Control/WHO Regional Office for Europe (2013) HIV/ AIDS surveillance in Europe 2012. Stockholm, European Centre for Disease Prevention and Control. http://ecdc.europa.eu/en/healthtopics/aids/ surveillance-reports/Pages/surveillance-reports. aspx. Zugegriffen: 24. Sept. 2015

95. Dehne KL, Khodakevich L, Hamers FF, Schwartländer B (1999) The HIV/AIDS epidemic in eastern Europe: recent patterns and trends and their implications for policy-making. AIDS 13:741-749

96. Bello G, Afonso JM, Morgado MG (2012) Phylodynamics of HIV-1 subtype F1 in Angola, Brazil and Romania. Infect Genet Evol 12:1079-1086

97. Burruano L, Kruglov Y (2009) HIV/AIDS epidemic in Eastern Europe: recent developments in the Russian Federation and Ukraine among women. Gend Med 6:277-289

98. Piot P, Quinn TC (2013) Response to the AIDS pandemic - a global health model. N Engl J Med 368:2210-2218

99. Ragupathy V, Devadas K, Tang S et al (2013) Effect of sex steroid hormones on replication and transmission of major HIV subtypes. J Steroid Biochem Mol Biol 138:63-71

100. Feng $Y, \mathrm{He} X, \mathrm{Hsi} J \mathrm{H}$ et al (2013) The rapidly expanding CRF01_AE epidemic in China is driven by multiple lineages of HIV-1 viruses introduced in the 1990s. AIDS 27:1793-1802

101. Schim van der Loeff MF, Aaby P (1999) Towards a better understanding of the epidemiology of HIV-2. AIDS 13(suppl A):S69-S84 
102. Rao VR, Neogi U, Talboom JS et al (2013) Clade C HIV-1 isolates circulating in Southern Africa exhibit a greater frequency of dicysteine motif-containing Tat variants than those in Southeast Asia and cause increased neurovirulence. Retrovirology 10:61

103. Chen M, Yang L, Ma Y et al (2013) Emerging variability in HIV-1 genetics among recently infected individuals in Yunnan, China. PLoS One 8:e60101

104. Han X, An M, Zhang W et al (2013) Genome sequences of a novel HIV-1 circulating recombinant form (CRF59_01B) identified among men who have sex with men in Northeastern China. Genome Announc 1:e00315-13

105. The Kirby Institute (2013) HIV, viral hepatitis and sexually transmissible infections in Australia Annual Surveillance Report 2013. The Kirby Institute, The University of New South Wales, Sydney

106. Churchill MJ, Chiavaroli L, Wesselingh SL, Gorry PR (2007) Persistence of attenuated HIV-1 rev alleles in an epidemiologically linked cohort of long-term survivors infected with nef-deleted virus. Retrovirology 4:43

107. MMWR (2013) HIV infection among heterosexuals at increased risk - United States, 2010. MMWR Morb Mortal Wkly Rep 62:183-188

108. CDC (2015) Today's HIV/AIDS epidemic. http:// www.cdc.gov/nchhstp/newsroom/HIVFactSheets/Epidemic/. Zugegriffen: 24. Sept. 2015

109. MMWR (2011) HIV-2 infection surveillance - United States, 1987-2009. MMWR Morb Mortal Weekly Rep 60:985-988

110. Aulicino PC, Gómez-Carrillo M, Bello G et al (2012) Characterization of full-length HIV1 CRF17_BF genomes and comparison to the prototype CRF12_BF strains. Infect Genet Evol 12:443-447

111. Gürtler L, Mühlbacher A, Michl U et al (1998) Reduction of the diagnostic window with a new combined p24 antigen and human immunodeficiency virus antibody screening assay. J Virol Methods 75:27-38

112. Janssen RS, Satten GA, Stramer SL et al (1998) New testing strategy to detect early HIV-1 infection for use in incidence estimates and for clinical and prevention purposes. JAMA 280:42-48

113. Kilembe W, Keeling M, Karita E et al (2012) Failure of a novel, rapid antigen and antibody combination test to detect antigen-positive HIV infection in African adults with early HIV infection. PLoS One 7:e37154

114. Mitchell EO, Stewart G, Bajzik O, Ferret M, Bentsen C, Shriver MK (2013) Performance comparison of the 4th generation Bio-Rad Laboratories GS HIV Combo Ag/Ab ElA on the EVOLIS ${ }^{\mathrm{TM}}$ automated system versus Abbott ARCHITECT HIV Ag/ Ab Combo, Ortho Anti-HIV $1+2$ ElA on Vitros ECi and Siemens HIV-1/O/2 enhanced on Advia Centaur. J Clin Virol 58(Suppl 1):e79-e84

115. Dalmau J, Puertas MC, Azuara M et al (2009) Contribution of immunological and virological factors to extremely severe primary HIV type 1 infection. Clin Infect Dis 48:229-238

116. Rabenau H, Bannert N, Berger A et al (2015) Nachweis einer Infektion mit Humanem Immundefizienzvirus (HIV): Serologisches Screening mit nachfolgender Bestätigungsdiagnostik durch Antikörper-basierte Testsysteme und/oder durch HIV-Nukleinsäure-Nachweis: Stellungnahme der Gemeinsamen Diagnostikkommission der Deutschen Vereinigung zur Bekämpfung von Viruskrankheiten e. V. (DVV e. V.) und der Gesellschaft für Virologie e. V. (GfV e. V.). Bundesgesundhblatt Gesundheitsforschung Gesundheitsschutz 58:877-886
117. AK Blut (2006) Votum 34. Bekanntmachung des Arbeitskreises Blut des Bundesministeriums für Gesundheit: Verfahren zur Rückverfolgung (Look Back) (gemäß § 19 Transfusionsgesetz. Bundesgesundhblatt Gesundheitsforschung Gesundheitsschutz 49:940-957

118. Bourinbaiar AS, Nagorny R, Tan X (1991) Heaviness of HIV particles in quantum relation to viral infectiousness and responsiveness to interferon. In: Andrieu JM (Hrsg) Viral Quantitation in HIV Infection. John Libbey Eurotext, Paris, S 41-52

119. Mühlbacher $A$, Schennach $H$, van Helden J et al (2013) Performance evaluation of a new fourthgeneration HIV combination antigen-antibody assay. Med Microbiol Immunol 202:77-86

120. Zaaijer HL, v Exel-Oehlers P, Kraaijeveld T, Altena E, Lelie PN (1992) Early detection of antibodies to HIV-1 by third-generation assays. Lancet 340:770-772

121. AK Blut (1994) Votum 2. Bewertung des HIV1-p24-Antigen-Test bei Blut- und Plasmaspenden. Bundesgesundhblatt Gesundheitsforschung Gesundheitsschutz 3:143

122. Salles NA, Levi JE, Barreto CC et al (2013) Human immunodeficiency virus transfusion transmission despite nucleic acid testing. Transfusion 53:2593-2595

123. Roth WK, Busch MP, Schuller A et al (2012) International survey on NAT testing of blood donations: expanding implementation and yield from 1999 to 2009. Vox Sang 102:82-90

124. Holmes H, Davis C, Heath A, Hewlett I, Lelie N (2001) An international collaborative study to establish the 1st international standard for HIV-1 RNA for use in nucleic acid-based techniques. J Virol Methods 92:141-150

125. Davis C, Berry N, Heath A, Holmes H (2008) An international collaborative study to establish a replacement World Health Organization International Standard for human immunodeficiency virus 1 RNA nucleic acid assays. Vox Sang 95:218-225

126. Holmes H, Davis C, Heath A (2008) Development of the 1st International Reference Panel for HIV1 RNA genotypes for use in nucleic acid-based techniques. J Virol Methods 154:86-91

127. Triques K, Coste J, Perret JL et al (1999) Efficiencies of four versions of the AMPLICOR HIV-1 MONITOR test for quantification of different subtypes of human immunodeficiency virus type 1. J Clin Microbiol 37:110-116

128. Yang C, Pieniazek D, Owen SM et al (1999) Detec tion of phylogenetically diverse human immunodeficiency virus type 1 groups $M$ and $O$ from plasma by using highly sensitive and specific generic primers. J Clin Microbiol 37:2581-2586

129. Wittek M, Stürmer M, Doerr HW, Berger A (2007) Molecular assays for monitoring HIV infection and antiretroviral therapy. Expert Rev Mol Diagn 7:237-246

130. Gröner A (2008) Pathogen safety of plasma-derived products - Haemate P/Humate-P. Haemophilia 14(Suppl 5):54-71

131. Chudy M, Weber-Schehl M, Pichl L et al (2012) Blood screening nucleic acid amplification tests for human immunodeficiency virus type 1 may require two different amplification targets. Transfusion 52:431-439

132. Chudy M, Kress J, Halbauer J, Heiden M, Funk MB, Nübling CM (2014) Risk minimization measures for blood screening HIV-1 nucleic acid amplification technique assays in Germany. Transfus Med Hemother 41:45-51
133. Müller B, Nübling CM, Kress J, Roth WK, De Zolt S, Pichl L (2013) How safe is safe: new human immunodeficiency virus type 1 variants missed by nucleic acid testing. Transfusion 53:2422-2430

134. Hourfar MK, Jork C, Schottstedt V et al (2008) Experience of German Red Cross blood donor services with nucleic acid testing: results of screening more than 30 million blood donations for human immunodeficiency virus-1, hepatitis $C$ virus, and hepatitis B virus. Transfusion 48:1558-1566

135. Morel $P$ (2011) Ten years of nucleic acid testing: lessons and prospects. Transfus Clin Biol 18:133139

136. Styer LM, Miller TT, Parker MM (2013) Validation and clinical use of a sensitive HIV-2 viral load assay that uses a whole virus internal control. J Clin Virol 58(Suppl 1):e127-e133

137. Holmes H, Berry N, Heath A, Morris C (2011) Preparation and evaluation of the 1st international standard for the quantitation of HIV-2 RNA in plasma. J Virol Methods 175:246-252

138. Robert Koch-Institut (2011) HIV-Infektionen/ AIDS Schätzung der Prävalenz und Inzidenz von HIV-Infektionen in Deutschland. Zur Situation in Deutschland - Eckdaten Meldepflichtige Infektionskrankheiten: Aktuelle Statistik 43. Woche 2011. Epid Bull 46:415-425

139. Robert Koch-Institut (2013) HIV-Infektion; in Infektionsepidemiologisches Jahrbuch meldepflichtiger Krankheiten für 2012. Robert Koch-Institut, Berlin, S 111-115

140. Bruhn R, Lelie N, Custer B, Busch M, Kleinman S (2013) Prevalence of human immunodeficiency virus RNA and antibody in first-time, lapsed, and repeat blood donations across five international regions and relative efficacy of alternative screening scenarios. Transfusion 53:2399-2412

141. DÄV (2010) Richtlinien zur Gewinnung von Blut und Blutbestandteilen und zur Anwendung von Blutprodukten - (Hämotherapie) - Gesamtnovelle 2005 mit Richtlinienanpassung 2010. Deutscher Ärzteverlag, Köln

142. AK Blut (2013) Befristete Rückstellung von der Blutspende bei Personen mit sexuellem Risikoverhalten -Stellungnahme des Arbeitskreises Blut (S 12) zum Beratungsergebnis der Bundesärztekammer. 11. Juli 2013. Bundesgesundhblatt Gesundheitsforschung Gesundheitsschutz 56:1340-1341

143. BÄK (Bundesärztekammer) (2012) Erläuterungen und Regelungsoptionen zum Blutspende-Ausschluss bzw. zur Rückstellung von Personen, deren Sexualverhalten ein Risiko für den Empfänger von Blutprodukten birgt. http://www.bundesaerztekammer.de/aerzte/medizin-ethik/wissenschaftlicher-beirat/veroeffentlichungen/haemotherapie-transfusionsmedizin/richtlinie/. Zugegriffen: 24. Sept. 2015

144. Offergeld R, Kamp C, Heiden M, Norda R, BehrGross ME (2014) Sexual risk behaviour and donor deferral in Europe. Vox Sang 107:420-427

145. PEI (2001) Bekanntmachung über die Zulassung und Registrierung von Arzneimitteln. Verminderung des Risikos von HIV-Infektionen durch zelluläre Blutprodukte und gefrorenes Frischplasma. Bundesanzeiger 90:9506-9507

146. Nübling CM, Heiden M, Chudy M et al (2009) Experience of mandatory nucleic acid test (NAT) screening across all blood organizations in Germany: NAT yield versus breakthrough transmissions. Transfusion 49:1850-1858

147. Kleinman SH, Lelie N, Busch MP (2009) Infectivity of human immunodeficiency virus-1, hepatitis $C$ virus, and hepatitis $B$ virus and risk of transmission by transfusion. Transfusion 49:2454-2489 
148. Weusten J, Vermeulen M, van Drimmelen H, Lelie N (2011) Refinement of a viral transmission risk model for blood donations in seroconversion window phase screened by nucleic acid testing in different pool sizes and repeat test algorithms. Transfusion 51:203-215

149. Bezemer D, van Sighem A, Lukashov VV et al (2010) Transmission networks of HIV-1 among men having sex with men in the Netherlands. AIDS 24:271-282

150. Stürmer $M$, Zimmermann $K$, Fritzsche $C$ et al (2010) Regional spread of HIV-1 M subtype B in middle-aged patients by random env-C2V4 region sequencing. Med Microbiol Immunol 199:123-128

151. AK Blut (2010) Votum 41. Verwendung eines einheitlichen Fragebogens für Blut- und Plasmaspender. Bundesgesundhblatt Gesundheitsforschung Gesundheitsschutz 53:862

152. Eberle J, Notheis G, Blattmann C et al (2010) Seroreversion in vertically HIV-1-infected children treated early and efficiently: rule or exception? AIDS 24:2760-2761

153. Muller E, Barday Z, Mendelson M, Kahn D (2015) HIV-positive-to-HIV-positive kidney transplantation - results at 3 to 5 years. N Engl J Med 372:613-620

154. WHO (2010) Antiretroviral therapy for HIV infection in adults and adolescents. Recommendation for a public health approach, 2010 revision. World Health Organization, Geneva

155. Schramm W, Rommel F, Kopel A, Puchta R (2000) Todesursachen und AIDS-Erkrankungen Hämophiler in Deutschland (Umfrageergebnisse 1998); in Scharrer I, Schramm W (eds): 29. Hämophilie-Symposium Hamburg 1998. Springer, Berlin, S 7-18

156. Unkelbach U, Hunfeld A, Breitner-Ruddock S (2014) Prüfung von aus gepooltem Plasma hergestellten Produkten. Bundesgesundhblatt Gesundheitsforschung Gesundheitsschutz 57:1181-1184

157. PEI (2014) Hämovigilanz-Bericht des Paul-EhrlichInstituts 2011/12: Auswertung der Meldungen von schwerwiegenden Transfusionsreaktionen nach § 63c AMG. http://www.pei.de/DE/arzneimittelsicherheit-vigilanz/haemovigilanz/haemovigilanzberichte/haemovigilanzberichte-node. html. Zugegriffen: 24. Sept. 2015

158. Schmidt M, Korn K, Nübling CM et al (2009) First transmission of human immunodeficiency virus type 1 by a cellular blood product after mandatory nucleic acid screening in Germany. Transfusion 49:1836-1844

159. an der Heiden M, Ritter S, Hamouda O, Offergeld $R$ (2015) Estimating the residual risk for HIV, HCV and HBV in different types of platelet concentrates in Germany. Vox Sang 108:123-130

160. Norrgren H, Andersson S, Biague AJ et al (1999) Trends and interaction of HIV-1 and HIV-2 in Guinea-Bissau, west Africa: no protection of HIV-2 against HIV-1 infection. AIDS 13:701-707

161. Parrish NF, Gao F, Li H et al (2013) Phenotypic properties of transmitted founder HIV-1. Proc Natl Acad Sci U S A 110:6626-6633

162. Loeb M, Eskandarian S, Rupp M et al (2011) Genetic variants and susceptibility to neurological complications following West Nile virus infection. J Infect Dis 204:1031-1037

163. Pauli G, Bauerfeind U, Blümel J et al (2012) WestNil-Virus. Bundesgesundhblatt Gesundheitsforschung Gesundheitsschutz 55:1024-1043
164. Rosenberg PS, Goedert JJ, Biggar RJ (1994) Effect of age at seroconversion on the natural AIDS incubation distribution. Multicenter Hemophilia Cohort Study and the International Registry of Seroconverters. AIDS 8:803-810

165. Rosenberg ES, Altfeld M, Poon SH et al (2000) Immune control of HIV-1 after early treatment of acute infection. Nature 407:523-526

166. Aberg JA (2012) Aging, inflammation, and HIV infection. Top Antivir Med 20:101-105

167. Stephenson KE, Barouch DH (2013) A global approach to HIV-1 vaccine development. Immunol Rev 254:295-304

168. Haynes BF, Moody MA, Alam M et al (2014) Progress in HIV-1 vaccine development. J Allergy Clin Immunol 134:3-10

169. Broder $S$ (2010) Twenty-five years of translational medicine in antiretroviral therapy: promises to keep. Sci Transl Med 2:39ps33

170. Jaffar S, Grant AD, Whitworth J, Smith PG, Whittle $H$ (2004) The natural history of HIV-1 and HIV2 infections of adults in Africa: a literature review. Bull World Health Organ 82:462-469

171. DAIG (2012) Deutsch-Österreichische Leitlinien zur antiretroviralen Therapie der HIV-Infektion. http://www.daignet.de/site-content/hiv-therapie/leitlinien-1. Zugegriffen: 24. Sept. 2015

172. Wei X, Decker JM, Liu H et al (2002) Emergence of resistant human immunodeficiency virus type 1 in patients receiving fusion inhibitor (T-20) monotherapy. Antimicrob Agents Chemother 46:1896-1905

173. Esposito F, Corona A, Tramontano E (2012) HIV-1 reverse transcriptase still remains a new drug target: structure, function, classical inhibitors, and new inhibitors with innovative mechanisms of action. Mol Biol Int 2012:586401

174. SagirA, Oette M, Kaiser R et al (2007) Trends of prevalence of primary HIV drug resistance in Germany. J Antimicrob Chemother 60:843-848

175. Menéndez-Arias L (2013) Molecular basis of human immunodeficiency virus type 1 drug resistance: overview and recent developments. Antiviral Res 98:93-120

176. Hirnschall G, Harries AD, Easterbrook PJ, Doherty MC, Ball A (2013) The next generation of the World Health Organization's global antiretroviral guidance. J Int AIDS Soc 16:18757

177. Duwe S, Brunn M, Altmann D et al (2001) Frequency of genotypic and phenotypic drug-resistant HIV-1 among therapy-naive patients of the German Seroconverter Study. J Acquir Immune Defic Syndr 26:266-273

178. Vercauteren J, Wensing AM, van der Vijver DA et al (2009) Transmission of drug-resistant HIV-1 is stabilizing in Europe. J Infect Dis 200:1503-1508

179. Geretti AM, Paredes R, Kozal MJ (2015) Transmission of HIV drug resistance: lessons from sensitive screening assays. Curr Opin Infect Dis 28:2330

180. Charpentier C, Camacho R, Ruelle J et al (2013) HIV-2 EU: supporting standardized HIV-2 drug resistance interpretation in Europe. Clin Infect Dis 56:1654-1658

181. Hütter G, Nowak D, Mossner M et al (2009) Long term control of HIV by CCR5 delta 32/delta 32 stem-cell transplantation. N Engl J Med 360:692698

182. www.hiv-druginteractions.org

183. Blanco J, Cabrera C, Jou A, Ruiz L, Clotet B, Esté JA (1999) Chemokine and chemokine receptor expression after combined anti-HIV-1 interleukin-2 therapy. AIDS 13:547-555
184. Goebel FD, Mannhalter JW, Belshe RB et al (1999) Recombinant gp160 as a therapeutic vaccine for HIV-infection: results of a large randomized, controlled trial. AIDS 13:1461-1468

185. Carcelain G, Autran B (2013) Immune interventions in HIV infection. Immunol Rev 254:355-371

186. Rerks-Ngarm S, Paris RM, Chunsutthiwat $S$ et al (2013) Extended evaluation of the virologic, immunologic, and clinical course of volunteers who acquired HIV-1 infection in a phase III vaccine trial of ALVAC-HIV and AIDSVAX B/E. J Infect Dis 207:1195-1205

187. Shao J, Chen J, Shen Y et al (2013) Identification of human immunodeficiency virus-1 (HIV-1) transmission from a 29-year-old daughter to her mother in Shanghai, China. Arch Virol 158:11-17

188. Gürtler LG, Eberle J, Bader L (1993) HIV transmission by needle stick and eczematous lesion three cases from Germany. Infection 21:40-41

189. Hawkins DA, Asboe D, Barlow K, Evans B (2001) Seroconversion to HIV-1 following a needlestick injury despite combination post-exposure prophylaxis. J Infect 43:12-15

190. Oksenhendler E, Harzic M, Le Roux JM, Rabian C, Clauvel JP (1986) HIV infection with seroconversion after a superficial needlestick injury to the finger. N Engl J Med 315:582

191. Katzenstein TL, Dickmeiss $\mathrm{E}$, Aladdin $\mathrm{H}$ et al (2000) Failure to develop HIV infection after receipt of HIV-contaminated blood and postexposure prophylaxis. Ann Intern Med 133:31-34

192. Al-Hajjar SH, Frayha HH, Al-Hazmi M et al (2014) Prevention of HIV-1 transmission with postexposure prophylaxis after inadvertent infected blood transfusion. AIDS 28:1539-1541

193. CPMP (1996) Note for guidance on virus validation studies: The design, contribution and interpretation of studies validating the inactivation and removal of viruses. CPMP/BWP/268/95. http://www.ema.europa.eu/docs/en_GB/document library/Scientific guideline/2009/09/ WC500003684.pdf. Zugegriffen: 24. Sept. 2015

194. Scheidler A, Rokos K, Reuter T, Ebermann R, Pauli G (1998) Inactivation of viruses by beta-propiolactone in human cryo poor plasma and lgG concentrates. Biologicals 26:135-144

195. Piët MP, Chin S, Prince AM, Brotman B, Cundell AM, Horowitz B (1990) The use of tri (n-butyl) phosphate detergent mixtures to inactivate hepatitis viruses and human immunodeficiency virus in plasma and plasma's subsequent fractionation. Transfusion 30:591-598

196. Dichtelmüller HO, Biesert L, Fabbrizzi F et al (2009) Robustness of solvent/detergent treatment of plasma derivatives: a data collection from Plasma Protein Therapeutics Associations member companies. Transfusion 49:1931-1943

197. Mauler R, Merkle W, Hilfenhaus J (1987) Inactivation of HTLV-III/LAV, hepatitis B and non-A/non-B viruses by pasteurization in human plasma protein preparations. Dev Biol Stand 67:337-351

198. Dichtelmüller H, Rudnick D, Breuer B et al (1996) Improvement of virus safety of a S/D-treated factor VIII concentrate by additional dry heat treatment at 100 degrees C. Biologicals 24:125-130

199. Stadler M, Gruber G, Kannicht C et al (2006) Characterisation of a novel high-purity, double virus inactivated von Willebrand factor and factor VIII concentrate (Wilate). Biologicals 34:281-288

200. Roberts PL, Dunkerley C, McAuley A, Winkelman $L$ (2007) Effect of manufacturing process parameters on virus inactivation by dry heat treatment at 80 degrees $C$ in factor VIII. Vox Sang 92:56-63 
201. Klamroth R, Gröner A, Simon TL (2014) Pathogen inactivation and removal methods for plasmaderived clotting factor concentrates. Transfusion 54:1406-1417

202. Prince AM, Horowitz B, Brotman B (1986) Sterilization of hepatitis and HTLV-III viruses by exposure to tri (n-butyl) phosphate and sodium cholate. Lancet 1(8483):706-710

203. Schimpf K, Brackmann HH, Kreuz W et al (1989) Absence of anti-human immunodeficiency virus types 1 and 2 seroconversion after the treatment of hemophilia A or von Willebrand's disease with pasteurized factor VIII concentrate. N Engl J Med 321:1148-1152

204. Pustoslemsek P, Kloft M, Kotitschke R (1993) Biotest-Stellungnahme zu HIV-1-Serokonversionen von 1990 an elf Patienten, die mit beta-Propiolacton/UV-virusinaktiviertem PPSB behandelt wurden. Infusionsther Transfusionsmed 20:344-346

205. Hanson CV, Riggs JL, Lennette EH (1978) Photochemical inactivation of DNA and RNA viruses by psoralen derivatives. J Gen Virol 40:345-358

206. Alter HJ, Creagan RP, Morel PA et al (1988) Photochemical decontamination of blood components containing hepatitis $B$ and non- $A$, non- $B$ virus. Lancet 2(8626-8627):1446-1450

207. Bachmann B, Knüver-Hopf J, Lambrecht B, Mohr H (1995) Target structures for HIV-1 inactivation by methylene blue and light. J Med Virol 47:172178

208. Singh Y, Sawyer LS, Pinkoski LS et al (2006) Photochemicl treatment of plasma with amotosalen and long-wavelength ultraviolet light inactivates pathogens while retaining coagulation function. Transfusion 46:1168-1177

209. Wagner SJ (2011) Developing pathogen reduction technologies for RBC suspensions. Vox Sang 100:112-121

210. Purmal A, Valeri CR, Dzik W et al (2002) Process for the preparation of pathogen-inactivated RBC concentrates by using PEN110 chemistry: preclinical studies. Transfusion 42:139-145

211. Reddy HL, Doane SK, Keil SD, Marschner S, Goodrich RP (2013) Development of a riboflavin and ultraviolet light-based device to treat whole blood. Transfusion 53(Suppl 1):131S-136S

212. Rock $G$ (2011) A comparison of methods of pathogen inactivation of FFP. Vox Sang 100:169178

213. Mufti NA, Erickson AC, North AK et al (2010) Treatment of whole blood (WB) and red blood cells (RBC) with S-303 inactivates pathogens and retains in vitro quality of stored RBC. Biologicals 38:14-19

214. Goodrich RP, Custer B, Keil S, Busch M (2010) Defining „,adequate" pathogen reduction performance for transfused blood components. Transfusion 50:1827-1837

215. AK Blut (1994) Votum 4: Minderung des Infektionsrisikos von Blut und Blutprodukten durch optimiertes Screening von Spendern. http:// www.rki.de/DE/Content/Kommissionen/AK_ Blut/Voten/Uebersicht/V_04/V04_Minderung_ Infektionsrisikos.html. Zugegriffen: 24 . Sept. 2015

216. EMA (2011) EMA/CHMP/BWP/706271/2010 Guideline on plasma-derived medicinal products, 21 Jul 2011. http://www.ema.europa.eu/docs/ en_GB/document_library/Scientific_guideline/2011/07/WC500109627.pdf. Zugegriffen: 24. Sept. 2015
217. Yamaguchi K, Sugiyama T, Kato S et al (2008) A novel CD4-conjugated ultraviolet light-activated photocatalyst inactivates HIV-1 and SIV efficiently. J Med Virol 80:1322-1331

218. Aghokeng AF, Ayouba A, Mpoudi-Ngole E et al (2010) Extensive survey on the prevalence and genetic diversity of SIVs in primate bushmeat provides insights into risks for potential new cross-species transmissions. Infect Genet Evol 10:386-396

219. Holmes EC, Nee S, Rambaut A, Garnett GP, Harvey PH (1995) Revealing the history of infectious disease epidemics through phylogenetic trees. Philos Trans R Soc Lond B Biol Sci 349:33-40 